\title{
CREATIVE NORM DESTRUCTION: THE EVOLUTION OF NONLEGAL RULES IN JAPANESE CORPORATE GOVERNANCE
}

\author{
CURTIS J. MILHAUPT ${ }^{\dagger}$
}

This Article analyzes the origins, persistence, and current evolution of a series of nonlegal rules (norms) that have played an important role in Japanese corporate governance. The central features of the governance environment examined here include: (1) the main bank system, in which banks voluntarily restructure lonns to some distressed borrowers, (2) a social distaste for hostile takeovers, (3) implicit promises of employment stability, and (4) belief systems about the proper role and structure of the board of directors.

I show that, despite virtually ubiquitous claims to the contrary, these norms do not enjoy a long history of practice in Japan, but rather emerged only in the immediate postwar period. I hypothesize that they emerged for two reasons: First, they served as a low-cost substitute for a troubled formal institutional environment beset by the "iransplant effect" that imperils legal reform in transition economies today. Second, they provided private benefits to the small number of interest groups that emerged intact from World War II. The flow of private benefits to norm adherents explains the persistence of the norms despite clear evidence of their inefficiency over the past decade.

I demonstrate that current madels of norm reform, which emphasize the role of exogenous shocks, the workings of norm entrepreneurs, and increased information, explain why the norms of Japanese corporate governance are currently evolving.

Finally, extrapalating from Japan's experience, I suggest how norm analysis can contribute to the two most pressing questions in comparative corporate govrnance today: whether law matters to corporate governance and whether diverse systems of corporate governance are converging toward the Anglo-American model. As to both questions, closer attention to norms reveals shortcomings in the existing literature. Specifically, the empirical model underlying the "law matters" literature is shown to be inconsistent with historical experience and overly attentive to formal

$\dagger$ Fuyo Professor of Law and Director, Center for Japanese Legal Studies, Columbia Law School. This Article grew out of a series of interviews I held in Tokyo with approximately twenty-five government officials, lawyers, investment bankers, and corporate managers in June of 2000 . Since several interviewees requested anonymity, I have cited to my interview transcripts without disclosing the identity of the interviewee. Interested (or skeptical) readers may review redacted transcripts upon request. I owe my interviewees a large debt of gratitude. Prior drafts were improved by comments from Robert Ellickson, Koichi Hamada, Michiyo Hamada, Hugh Patrick, Gary Saxonhouse, Mark West, my symposium commentator Reinier Kraakman, and symposium or workshop participants at Columbia University, University of Michigan, University of Pennsylvania, and Vanderbilt University Law Schools, and the American Law and Economics Association Annual Meeting. I also benefited from discussions with Melvin Eisenberg. 
rules enforced by courts. Bold claims that we are witnessing rapid convergence toward a shareholder-centered ideology, which in turn will drive convergence of $c o r$ porate law and practices, are only partially supported by the Japanese experience to date. Rather than the "end of history" for corporate law, we are witnessing an ongoing struggle to align the formal and informal components of the governance regimes of many transition economies, including Japan's.

\section{INTRODUCTION}

As this Symposium attests, the role of norms in the corporation has only recently attracted the attention of legal scholars." This is curious, given the depth of analysis previously devoted to the role social norms play in governing collective behavior among cattle ranchers, diamond merchants, sumo wrestlers, and other exotica. ${ }^{2}$ The importance, if not the novelty, of these well-studied groups pales in comparison to the corporation, arguably the most ingenious private organization ever devised.

Perhaps even more curiously, social norms have been virtually ignored in the comparative corporate governance debates of the past decade. The omission of norms from this body of literature is particularly stark. It is now widely recognized, for example, that legal protections for minority investors are a key variable in determining patterns of corporate ownership and finance around the world. Yet the literature to date (which ironically has been dominated by economists) displays a rather naive fixation on formal legal protections and judicial enforcement to the exclusion of other alternatives. To take another example, analysis of complements and substitutes has been used powerfully to explain major phenomena in comparative corporate law, including the stickiness of institutional change and the unintended consequences of legal transplants. But this conceptual framework has not been brought to bear on the interaction between legal and nonlegal rules in the governance of firms. Perhaps most glaringly, for all the recent discussion of global convergence on a shareholder-centered model of corporate governance, there have been remarkably few careful examinations of the linkage between corporate norm shifts and

1 Two noteworthy exceptions are Melvin A. Eisenberg, Corporate Law and Social Norms, 99 Colum. L. REv. 1253 (1999), and Edward B. Rock, Saints and Sinners: How Does Delaware Corporate Law Work?, 44 UCLA L. REv. 1009 (1997).

${ }^{2}$ ROBERT C. ELLICKSON, ORDER WTHHOUT LAW: HOW NEIGHBORS SETTLE DISPUTES (1991) (cattle ranchers); Lisa Bernstein, Opting Out of the Legal System: Extralegal Contractual Relations in the Diamond Industry, 21 J. LEGAL STUD. 115 (1992) (diamond merchants); Mark D. West, Legal Rules and Social Norms in Japan's Secret World of Sumo, 26 J. LEGAL STUD. 165 (1997) (sumo wrestlers). 
changes in corporate law and practice.

As a modest step toward filling these gaps in the literature, in this Article I examine the creation, persistence, and evolution of a series of highly complementary, nonlegally enforceable practices that shaped postwar corporate governance for large Japanese firms. I examine four central features of the governance environment: (1) the "main bank" system and its role in corporate monitoring, (2) the absence of an external market for corporate control, (3) the structure and role of Japanese boards, and (4) the lifetime employment system. Examining these components of Japanese corporate governance is certainly not novel. Analyzing them as norms, however, yields some fresh insights into how nonlegal rules interacted with the legal system during the heyday of Japanese corporate governance, why the norm-based system persisted long after evidence of its inefficiency emerged, and how (or whether) Japan is currently adapting to a shareholder-centered ideology of corporate governance. Most interestingly, Japan's experience with corporate norms-which as we shall see is intimately related to its three experiences as a transition economy-sheds light on a current debate about the role of law in corporate governance. This debate is itself an outgrowth of the past decade of institutional disarray in many transition economies of Eastern Europe and Asia.

This Article has two principal aims: First, to contribute to the limited store of primary research on norms by analyzing their role in the governance of firms in the world's second largest economy. Primary research on norms of all types is in short supply, but research on the operation of norms among organizations is virtually nonexistent. ${ }^{3}$ The second aim is to draw attention to the lack of norm analysis in comparative corporate governance scholarship. The Article does so by illustrating, based on the Japanese experience, how norm analysis contributes to the two most interesting questions in comparative corporate governance today: Do legal differences explain cross-country differences in corporate ownership and finance, and are corporate governance systems converging?

The Article is organized as follows: Part I describes four norms that are intimately connected to Japanese corporate governance practices in the postwar period. Part II demonstrates, despite numerous claims to the contrary, that each of these norms first emerged in the

"The sole exception may be an article prepared for this Symposium. Robert Cooter \& Melvin A. Eisenberg, Good Agent Character, Faimess, and Efficiency in Firms, 149 U. PA. L. REV. 1717 (2001). 
postwar period and represents a break with past practices. This insight provides important clues about the origins and durability of the norm-based system. I hypothesize that the new norms emerged as both low-cost substitutes for legal rules in the institutional turmoil of the immediate postwar period and as a fount of private benefits for the few organized groups left intact after the war and Allied occupation. Normative corporate governance, I argue, was a postwar Japanese invention understandable through the lenses of transaction cost economics and public choice theory. Part III explores the ongoing evolution of the postwar norms of Japanese corporate governance, reflecting shifts in the relative costs of using legal versus nonlegal rules, reconfigurations of the players in Japanese corporate governance, increased information, and the workings of norm reformers, including those within the government. Drawing on the creation and destruction of nonlegal rules in corporate Japan, Part IV highlights the contribution of norm analysis to the two key debates in comparative corporate law scholarship today.

Before proceeding, a definition and two caveats are in order. One of the principal problems with norm analysis is the lack of agreement on the definition of the term. In this Article, I have adopted Richard Posner's definition: a norm is "a rule that is not promulgated by an official source, such as a court or a legislature, nor enforced by the threat of legal sanctions, yet is regularly complied with." This definition does not require that a rule be internalized as a preference ${ }^{x}$ or that it be deeply rooted in the culture that complies with it. Unlike many other definitions in use, it does not place particular emphasis on social enforcement, thus highlighting the possibility that norms can be self-enforcing if compliance generates private benefits. The first caveat is that, for reasons made clear below, several of the rules I am about to discuss fall marginally outside that definition because they depend in some way on the government for promulgation or enforcement. I have included them because their informal character substantially outweighs the support they draw from the state and because the intermeshing of norms and state-generated rules is one of the key themes emerging from our inquiry. The second caveat is that these norms apply only to the governance of large, publicly held firms.

${ }^{4}$ Richard A. Posner, Social Norms and the Law: An Economic Approach, 87 AM. ECON. Rev., PAPERs AND Procs. OF the Hundred AND NinTH ANN. MEeting of the AM. ECON. Ass'N, May 1997, at 365, 365.

${ }^{5}$ Id. at 365 n.1. 


\section{Four NONLEGAL RULES OF JAPANESE CORPORATE GOVERNANCE}

The stylized account of Japanese corporate governance for large firms contains several key features: the "main bank" system, in which banks are said to perform the key monitoring role over their client firms; the concomitant absence of an external market for corporate control; employee-dominated boards that focus on day-to-day management rather than monitoring; and the lifetime employment system, in which certain employees enjoy implicit promises of careerlong job stability. This Part examines the normative features of these arrangements. My point here is not that law is irrelevant to Japanese corporate governance." Rather, it is to highlight the distinction between institutions (endogenously generated, self-enforcing informal rules, including beliefs) and law, and to show how important the former are to the Japanese firm.

\section{A. Norms Governing the Main Bank System}

Perhaps the principal distinguishing feature of Japanese corporate governance is the main bank system. The main bank, at least as it operated in its heyday, can be characterized as the largest single lender to a corporate client as well as one of its principal shareholders. As a central repository of information on the borrower, the main bank was well positioned to play a key role in monitoring the firm's management and rendering assistance in case of managerial crisis or financial failure. ${ }^{\gamma}$ This assistance could include loan forgiveness and guarantees of outstanding and new indebtedness.

The main bank is not a legal institution. Its function is not de-

"I have argued elsewhere that the formal legal structure in Japan supports corporate private ordering in crucial ways. Curtis J. Milhaupt, A Relational Theory of Japanese Corporate Governance: Contract, Culture, and the Rule of Law, 37 HARV. INT'L L.J. 3 (1996); ier also J. MARK RAISEYER \& MINORU NAKAZATO, JAPANESE LAW: AN ECONOMIC APPROACH 2-3 (1999) (arguing that the Japanese legal system provides proper incentives for economic growth).

${ }^{7}$ I am following the lead of Stanford economist Masahiko Aoki in drawing this distinction. Aoki focuses exclusively on the main bank system. See Masahiko Aoki, A Note on the Role of Banking in Developing Economies in the Aftermath of the East Asian Crisis (1999) (unpublished manuscript, on file with author).

"I make no claims here about the quality or economic effects of main bank monitoring. Those questions are currently being reassessed in light of Japan's economic malaise. Sec, e.g., Christopher W. Anderson \& Terry Campbell II, Corporate Governance of Japanese Banks 30 (2000) (unpublished manuscript, on file with Social Science Research Network), available at http://papers.ssrn.com/sol3/papers.cfm?cfid= $22860+\&$ cftoken $=85393283 \&$ abstract_id $=231950$. 
fined in any statute or regulation. Nor are any special obligations to borrowers specified contractually. ${ }^{9}$ Rather, the main bank system rests on a social presumption. A "prominent part of the business ideology surrounding the main bank system"10 is the expectation on the part of the bank, the borrower, and all relevant business and governmental actors that a main bank informally restructures a large failing company rather than foreclosing on its loans. In these informal workout scenarios, the main bank typically waives a portion of the debt in return for a restructuring plan by the borrower. ${ }^{11}$ Although the main bank almost always has a first priority security interest in the collateral of the debtor, the bank, in effect, voluntarily subordinates its interest to that of the other lenders.

Why does the main bank undertake this role? This question is the subject of a vast literature that I will not summarize here. The key for present purposes is that, as Geoffrey Miller and I have argued elsewhere, the entire main bank system is supported by a cluster of norms that encourage banks to support weak firms (at least those for which a return to solvency and profitability are possible) in return for a nonlegally enforceable promise by the government to prevent bank failure. ${ }^{12}$ Indeed, until the early 1990s, there was not a single Japanese

9 See Aoki, supra note 7; see also J. Mark Ramseyer, Explicit Reasons for Implicit Contracts: The Legal Logic to the Japanese Main Bank System, in THE JAPANESE MAIN BANK SYSTEM: ITS RELEVANCE FOR DEVELOPING AND TRANSFORIING ECONOMIES 231, 231 (Masahiko Aoki \& Hugh Patrick eds., 1994) (describing the main bank system as a "nexus of implied contracts" or "promises ... never made").

${ }^{10}$ Paul Sheard, The Main Bank System and Comporate Monitoring and Control in Japan. 11 J. ECON. BEHAV. \& ORG. 399, 407 (1989).

"See Phred Dvorak, Japan Readies New Remedy on Bank Debt, WALl ST. J., Mar. 5. 2001, at A14 (reporting that 235 companies received informal debt waivers from 1985 to April 2000).

${ }^{12}$ Curtis J. Milhaupt \& Geoffrey P. Miller, Cooperation, Conflict, and Convergence in Japanese Finance: Evidence from the “Jusen” Problem, 29 LAW \& POL'Y INT'L BUS. 1, 19-20 (1997). Paraphrasing slightly, we described the norms in the following terms:

- Survival of the Weakest. Policies (rates) are set to permit the survival of the weakest member of the group. The weakest member of the group is often the one most likely to defect from the group's norms because the benefit this member obtains from abiding by those norms may be outweighed by the benefit it can obtain through defection. Because defection by one member can threaten the entire structure, the weakest member has a credible threat that places it in a strong bargaining position vis-à-vis its counterparts. In consequence, the substantive norms of the group are likely to protect the weakest member in order to insure this member's continuing loyalty to the group.

The norm of Survival of the Weakest benefits the stronger as well as the weaker members. In addition to enhancing the durability of the group as a whole, the Survival of the Weakest norm may support pricing arrangements that allow the weakest member to stay in business while allowing more efficient producers to 
bank failure in the postwar period.

\section{B. The Norm Against Hostile Takeovers}

Closely linked to the main bank system is the second major distinguishing characteristic of Japanese corporate governance, the absence of a market for corporate control. Indeed, there have been virtually no contested bids among Japanese firms in the postwar period. Hostile takeovers have thus played no disciplining role over Japanese management. This function, to the extent it existed, was subsumed within the operation of the main bank system itself. Failing firms were often restructured under the guidance of the main bank, generally resulting in the replacement of existing management. Transfers of corporate assets are so heavily intermediated by banks that the tender offer process was used only three times from its inception in 1971 through $1990 .^{13}$

earn supercompetitive profits.

- No Exit (No Failure): Almost a corollary of the principle of Survival of the Weakest is that of No Exit: no group member is allowed to exit (fail). This enhances stability both by preventing failure by weaker members and by increasing public confidence in the management of the group.

- Responsibility and Equitable Subordination: When the danger of financial failure grows, the parent or principal source of funding for the failing entity is expected to take responsibility by extending financial assistance and by subordinating its claims to those of other creditors, even if not legally required to do so. This norm encourages monitoring by stronger group members by imposing both monetary and reputational costs on stronger players who allow smaller players under their jurisdiction to fall into difficulty.

- Implicit Government Insurance: The preceding norms lead naturally to a substantive norm of implicit insurance provided by the government. If strong members are expected to assist weaker members and if no member of the group is allowed to fail, some entity must backstop the strong members. Thus, an implicit grant of government insurance is inherent in the operation of the other norms. Put differently, the Responsibility and Equitable Subordination norm extends even to the government.

There are a few examples of bank defection from these norms in the 1970s and 1980s. However, the most prominent of these, involving the bankruptcy of Sanko Steamship $C_{0}$, in 1985 , actually underscores the existence of powerful nonlegal rules in the banking industry. Sanko was forced to file for protection from its creditors in 1985 when its three principal lenders refused to extend additional financing to the struggling firm. But prior to the banks' defection, both Sanko and the government defected as well: Sanko resisted the banks' attempts to play a larger role in its management, and the government refused to provide explicit guarantees to the banks. See Japanest' Shipping Firm Sinks, CHICAGo SUN-TMIES, Aug. 14, 1985, available at $1985 \mathrm{WL}$ 3576487; Masayoshi Kanabayashi, Japan's Sanka Faces Pressure To Seek Relief, WaLL ST. J., Aug. 13, 1985, available at 1985 WL-WSJ 225942.

1: Hideki Kanda, Comparative Comporate Governance Country Report: Japan, in 
To be sure, there are legal and structural impediments to hostile takeovers in Japan. The most formidable is the practice of stable cross-shareholding among Japanese firms and banks, most prominently in the form of the keiretsu corporate groups. As Mark Ramseyer has noted, while these obstacles do not prevent hostile takeovers, they do make them more expensive relative to the alternatives." There may also be a host of more subtle reasons for the lack of hostile takeover activity. For example, because a high percentage of directors of public firms are alumni cohorts of a small number of prestigious universities, the managers of the erstwhile bidder and target could well be classmates, particularly given the seniority-based promotion system of most large firms. ${ }^{15}$

Interesting for our purposes, however, is the fact that these impediments are shrouded in a firmly established social norm. The shared understanding that Japanese managers do not sell their companies, particularly to an uninvited bidder, is repeated like a mantra in virtually every domestic and foreign commentary on Japanese mergers and acquisitions ("M\&A"). The following account of the norm by a foreign observer is representative:

[T] he Japanese company is an extension of the concept of the family; the company cannot be separated from the people who comprise it. The sale of a Japanese business, therefore, is said to have the flavor of the sale of people. It is said to be immoral. Even the Japanese vocabulary used in acquisitions supports this view. The purchase of a company in Japan is called "nottori," which can be translated as "a hijacking."

It is impossible to determine whether the structural impediments, the subtle factors, the norm, or some combination of the above is actually doing the work of dampening the market for corporate control in Japan. Nonetheless, the very existence of such a pervasive social

Comparative Corporate Governance: THE STATE OF THE ART AND EMERgiNg RESEARCH 921, 934 (Klaus Hopt et al. eds., 1998).

${ }^{14} \mathrm{~J}$. Mark Ramseyer, Takeovers in Japan: Opportunism, Ideology, and Corporate Control, 35 UCLA L. REV. 1, 38 (1987). For an excellent overview of obstacles to mergers and acquisitions ("M\&A") in Japan, see Berkeley Scott, $M \mathcal{E}$ 'A Japan: An Update from Morgan Stanley, BUS. INSIGHT JAPAN, Nov. 1998, at http://bi-japan.com/1998/nov/bijapanwww/zashi/dm2.htm.

${ }^{15}$ This possibility emerged from a discussion with Robert Rasmussen. Indeed, just under fifty percent of the presidents of firms having capital of at least $¥ 100$ billion in 1995 were graduates of the University of Tokyo. Setsuo Miyazawa \& Hiroshi Otsuka, Legal Education and the Reproduction of the Elite in Japan, 1 AstAN-PAC. L. \& POL'YJ. 1, 20 \& tbl.25 (2000), available at http://www.hawaii.edu/aplpj/1/02.html.

${ }^{16}$ Kelly Charles Crabb, The Reality of Extralegal Barriers to Mergers and Acquisitions in Japan, 21 INT'L LAW. 97, 116 (1987) (citations omitted). 
understanding seems significant. Even if its effects are overwhelmed by more prosaic disincentives to hostile bids, the emergence and persistence of a "trivial" social norm remains to be explained.

\section{Beliefs About Board Structure and Role}

There is a sizeable gap between Japanese corporate law and practice on the composition and role of the board of directors. In contrast to the German system of codetermination, Japanese law does not require employee participation at the board level. Yet Japanese boards are comprised almost exclusively of managers who have served the corporation throughout their career and are viewed as employee representatives. ${ }^{17}$ Legally, the Japanese board is charged with monitoring corporate activity and vested with the authority to make important managerial decisions. ${ }^{18}$ In fact, boards have not traditionally emphasized their monitoring role. Moreover, it is commonly understood that a few senior directors (acting as an informal management committee) or a representative director (who is virtually always the president) have the ultimate decisionmaking authority in the corporation, rather than the board as a whole. These discrepancies between law and practice recently led a blue ribbon corporate governance panel to conclude that "[i]t is questionable whether the Japanese board of directors actually complies with the Commercial Code's stipulation that it function[] as the body which decides on corporate will and exercises corporate oversight."

The gaps between law and practice can be traced to beliefs about the board's proper function in the Japanese system. Election to the board has traditionally been viewed almost exclusively as the crowming achievement in a long career with the firm that begins upon graduation from college. As noted above, virtually all members of the board have traditionally been members of senior management (typically one from each of the company's major divisions). ${ }^{20}$ Indeed, the Commercial Code does not even recognize officers as a distinct corporate organ, suggesting that the concepts are indistinct. The fact that senior managers are almost never hired away from competitors or firms in

"Corporate Governance Conm., Corporate Governance Forum of Japan, CORPORITE GOIERNANCE PRINCIPLES-A JAPANESE VIEW 41-42 (1998).

's SHōHō [Commercial code], Law No. 48 of 1899, art. 260.

" CORPORATE GovernaNCE COMM., supra note 17, at 49 .

"Id.; see also WILlLAM M. MERCER COMPANIES LlC, TORISHIMARTYakU INOBEISHON [DIRECTOR INNOVATION] 49 (1999) [hereinafter DIRECTOR INNOVATION]. 
other industries reinforces the perception that directors represent employees or, at most, divisions of the firm.

This belief system shaped the two defining characteristics of the traditional Japanese board, its large size and lack of independent directors and committees. ${ }^{21}$ A survey of all listed companies in Japan found that the boards of firms with more than 1000 employees had an average of 17.7 directors. Among the same firms, $22 \%$ had 20 to 24 directors and $10 \%$ had 25 or more directors. ${ }^{22}$ The friendly merger of two large Japanese banks once created a board of $67 .^{23}$

The common practice of having a very large board composed almost exclusively of senior managers is consistent with the view of board seats as incentive devices for loyal employees. The practice, however, is harder to square with the legal conception of the board as the locus of corporate monitoring and strategic decisionmaking. ${ }^{24}$

\section{Lifetime Employment}

Another principal feature of Japanese corporate structure is the "lifetime" employment system, which covers white-collar and most blue-collar workers in large firms. In this system, the mutual expectation of employer and employee is that the employee will enjoy continuous employment until the mandatory retirement age. Wages that undercompensate for productivity at the outset of the employment relationship are eventually offset by wages that overcompensate for productivity in the latter stages of the employee's career. Semi-annual bonuses, an integral part of the salary structure, are loosely tied to firm performance and pensions are generally not portable. Because labor mobility is limited and the employee has in effect posted a bond at the outset of the employment relationship that will only be fully recouped upon retirement, employees have a significant vested interest

${ }^{21}$ See CORPORATE GOVERNANCE COMM., supra note 17, at 41-42 (noting the difficulties of achieving board independence).

${ }^{22}$ DIRECTOR INNOVATION, supra note 20, at 20-21. A study by Steven Kaplan found that Japanese firms had a median of 21 directors, while U.S. firms had a median of 15. Steven N. Kaplan \& J. Mark Ramseyer, Those Japanese Firms with Their Disdain for Shareholders: Another Fable for the Academy, 74 WASH. U. L.Q. 403, 410 (1996). at 75 .

${ }^{23}$ The Skies Are Darkening over Japan's Big Bank Mergers, ECONOMIST, May 27, 2000,

${ }^{24}$ CoRPORATE GOVERNANCE COMM., supra note 17 , at 49 . CalPERS believes the Japanese view of the board as a status position bestowed upon long-term employees as a reward for loyal service is in direct conflict with the monitoring and decisionmaking role of the board. CalPERS, Japan Market Principles, http://www.calpersgovernance.org/principles/international/japan/page04.asp (1999). 
in the continued viability and success of their firms.

Lifetime employment is not legally mandated. Nonetheless, treating lifetime employment as a norm requires qualification, because law has played an important role in shaping this institution. Japanese courts have supported the lifetime employment system by supplying bargaining endowments to both employers and employees, resulting in malleable, long-term employment patterns. ${ }^{25}$ For employees, judicial precedent places substantial constraints on an employer's ability to dismiss workers even where layoffs are motivated by economic necessity. For employers, doctrine supports adjustment of work rules and ambiguous demarcation of job requirements, providing flexibility in worker assignments and transfers. Thus, important aspects of lifetime employment are legally enforceable.

At the same time, however, it is unlikely that the threat of legal sanction was the primary motivation of Japanese firms in entering into long-term, open-ended employment relationships with key workers. While some cases on abusive dismissal predate the emergence of lifetime employment practices, the Supreme Court did not affirm the standards developed in the lower courts until 1975. Furthermore, many of the important cases restricting layoffs arose out of the oil crisis of the 1970s and the yen crisis of the 1980s, long after lifetime employment practices were firmly entrenched. More importantly, the judicial standards for dismissal apply to a much larger universe of employees than those covered by lifetime employment, ${ }^{26}$ indicating that implicit promises of career-long employment security are not the only available response to the legal requirements.

Professors Ronald Gilson and Mark Roe hypothesize that lifetime employment grew out of a political deal in which favored workers were granted employment security in return for labor peace and cooperation. ${ }^{27}$ They characterize lifetime employment as "political" to emphasize the noneconomic rationale driving the formation of the institution. But their account is consistent with the view that lifetime employment arose out of a larger social pact to bring stability to post-

For further analysis of the importance of judge-made law in the development of Japanese employment practices, see Takashi Araki, Flexibility in Japanese Employment Relations and the Role of the Judician;, in JAPANESE COMAIERCLAL LAW IN AN ERA OF INTERNATIONALIZATION 249 (Hiroshi Oda ed., 1994).

Id. at 253-54.

${ }^{27}$ Ronald J. Gilson \& Mark J. Roe, Lifetime Employment: Labor Peace and the Evolution of Japanese Corporate Gavernance, 99 COLUM. L. REV. 508, 522-23 (1999). 
war Japan. ${ }^{28}$ Indeed, the origins of lifetime employment are echoed in the judicial standards on abusive dismissal, under which layoffs must be "objectively reasonable and socially appropriate." Viewed in this light, lifetime employment is a social norm that has been sanctioned and diffused by the state. ${ }^{30}$

It is now common to analyze corporate governance institutions in a given country as a system of complementary components, meaning that the system as a whole is greater than the sum of the individual parts. $^{31}$ The nonlegal rules of Japanese corporate governance, particularly in conjunction with cross-shareholding practices, clearly constitute a complementary system. Bank monitoring, for example, has greater impact where share ownership is concentrated and lifetime employment is the norm; it would have less effect where ownership is dispersed, the market for corporate control is active, or senior managers are recruited from outside the firm. ${ }^{32}$ A tradition of nonlegal governance may itself be complementary to bank monitoring. It has been argued that bank monitoring is actually enhanced by a low level of legal enforcement, since it reduces liability disincentives to active participation in the oversight of client firms. ${ }^{33}$ The absence of a hostile takeover market in a system of bank monitoring, in turn, makes credible the implicit promise of lifetime employment, which reinforces beliefs about the proper role of management and the structure of the board.

Less well understood, however, is a question the seminal literature explicitly sidesteps: how are diverse actors led to pursue coherent policies and practices that result in complementary systems? ${ }^{3+}$ We

${ }^{28}$ In fact, Gilson and Roe expressly leave room for this interpretation. Id. at 523 (hypothesizing that the deal was "cemented by an emergent norm or 'macro' political understanding").

${ }^{29}$ Ichikawa v. Nihon Shokuen Seizō Co., 29 MiNshū 456, 458 (Sup. Ct., Apr. 25. 1975).

${ }^{30}$ For a similar conclusion, see Daniel $\mathrm{H}$. Foote, Judicial Creation of Norms in Japanese Labor Law: Activism in the Service of-Stability?, 43 UCLA L. REV. 635, 651 (1996).

${ }^{31}$ The seminal article is Paul Milgrom \& John Roberts, Complementarities and Systems: Understanding Japanese Economic Organization, 9 EsTudros EcoNoMICOS 3 (1994).

${ }^{32}$ These examples come from Hideki Kanda, Japan's Financial Big Bang: Its Impact on the Legal System and Corporate Governance, in CRISIS AND CHANGE IN THE JAPANESE FINANCIAL SYSTEM 277, 281-82 (Takeo Hoshi \& Hugh Patrick eds., 2000).

33 Id. at 284 .

${ }^{34}$ Milgrom \& Roberts. supra note 31, at 19. 
turn now to this question. As we will see, in Japan individual governance components were bonded into a complementary whole by normative glue emerging out of the distinctive environment surrounding World War II.

\section{NORM CREATION AND THE DEMAND FOR CORPORATE LAW}

Why did these corporate governance norms emerge and how did they interact with the corporate law? Fortunately, it is possible to identify the historical period in which all of the corporate norms just discussed emerged. Knowing the historical context makes it possible to develop a hypothesis about how the norms emerged and why they persisted.

\section{A. Origins and Persistence of Normative Corporate Governance}

Tracing the origins of social norms is no small task, and I do not claim to have definitive historical evidence linking the emergence of normative corporate governance in Japan to the actions of individual actors. Yet one thing is clear: although claims to the contrary are virtually ubiquitous, none of the norms just described is deeply rooted in Japanese culture or reflects longstanding business customs.

On the contrary, the corporate governance norms surveyed above are a postwar Japanese invention. ${ }^{35}$ Indeed, evidence of common prewar practices contrary to each of the four norms is not hard to find. For example, the main bank system did not exist in the first major phase of modern Japanese economic growth, the Meiji and Taisho periods (1868-1925), nor did any system of bank-oriented corporate governance. ${ }^{\text {si }}$ Crucially, the government's implicit insurance against bank failure, which animates the main bank norms, was not in place

"Strictly speaking, the institution that would become the postwar main bank system had its origins in wartime loan syndicates guided by the government. Juro Teranishi, Lonn Syndication in War-Time Japan and the Origins of the Main Bank System, in THE J.APANESE MLIN B.ANK SYSTEM, supra note 9, at 51.

The governance of firms is not the only place where a bit of digging reveals the shallowness of Japanese claims to deep historical roots. See MIRRor of Modernity: INVENTED TRIDITIONS OF MODERN JAPAN (Stephen Vlastos ed., 1998) (finding recent origins of many "age old" Japanese practices and cultural icons, including the rituals of sumo wrestling, aversion to litigation, and domesticity ideals).

"Yoshiro Miwa \& J. Mark Ramseyer, Banks and Economic Growth: Implications from Japanese History 33-35 (Aug. 2000) (unpublished manuscript, on file with Social Science Research Network), available at http://papers.ssrn.com/sol3/ papers, cfm: cfid $=4286048$-cftoken $=853932838$ :abstractid $=239957$. 
before World War II. At least in the 1920s and 1930s, the Japanese government did not interfere with market discipline on banks, and bank failures were numerous. ${ }^{37}$

Mergers and acquisitions were also common in the Meiji Period. The family-controlled conglomerates known as zaibatsu frequently used acquisitions, including hostile takeover bids, as a strategic means of entering and developing industries. ${ }^{38}$ Moreover, in the 1950 s, several former zaibatsu firms were threatened by hostile bids. Managerial fear of hostile bids may have been an impetus for the practice of crossshareholding, which emerged about this time. ${ }^{39}$

Finally, prewar practices at the board and employee levels also differed from the patterns previously discussed in this Article. For example, there is evidence that during the turn of the last century outside directors served on many boards and played an important role in monitoring firms. ${ }^{40}$ Perhaps most surprisingly, employment relations through World War II are best described as insecure, as high rates of turnover and a mutual lack of long-term commitment on the part of employers and employees predominated. ${ }^{41}$ In short, prewar Japanese corporate governance shared more traits with the present AngloAmerican system than with its postwar reincarnation.

Why did norms at odds with past practices emerge to create the defining characteristics of postwar Japanese corporate governance?

${ }^{37}$ NIHON GINKō [BANK OF JAPAN], SENZENKI NI OKERU HATAN GINKō SEIRI NO JIREI [EXAMPLES OF FAILED BANK RESOlutions IN THE PREWAR PERIOD] (1998) (showing major capital and deposit write-offs for failed banks during a financial crisis in the 1920s).

${ }^{38}$ See TOMaTSU \& Co., YOKU WAKarU M\&A [UNDERSTANDING M\&A] 28 (2000); Zenichi Shishido, Reform in Japanese Corporate Law and Corporate Governance: Current Changes in Historical Perspective 2 (Nov. 45, 1999) (unpublished manuscript, on file with author).

${ }^{39}$ See Randall Morck \& Masao Nakamura, Japanese Corporate Governance and Macroeconomic Problems 8-9 (Apr. 2000) (unpublished manuscript, on file with Social Science Research Network), available at http://papers.ssrn.com/sol3/ papers.taf?cfid $=428604 \&$ cftoken $=85393283 \&$ cabstract_id= $=235758$.

${ }^{40}$ Yoshiro Miwa \& J. Mark Ramseyer, The Value of Prominent Directors: Lessons in Corporate Governance from Transitional Japan 6-7 (Nov. 2000) (unpublished manuscript, on file with Social Science Research Network), available at http://papers.ssrn.com/sol3/papers.cfm?cfid=428604\&cftoken=85393283\&abstract_id $=192388$.

${ }^{41}$ See, e.g., ANDREW GORDON, THE EVOLUTION OF LABOR RELATIONS IN JAPAN: HEAVY INDUSTRY 1853-1955, at 132-61 (1985) (discussing pre-World War II trends in employment relations and variations in commitment level); Gilson \& Roe, supra note 27, at 518-20 ("Stable employment is not a continuous Japanese cultural tradition.... Yearly turnover rates of around seventy-five percent were the norm in most industries during World War I."); Shishido, supra note 38, at 3. 
Part of the answer, as other scholars have recognized, is that World War II created new patterns of interaction between government and industry that left an indelible mark on Japan's economic structures. ${ }^{42}$ The National General Mobilization Law, enacted in 1938, provides insight into how the exigencies of wartime production could have reoriented thinking about the organization of firms. ${ }^{43}$ The purpose of the law, which vested the government with vast power over all facets of labor, capital, contracting, and the operation of commercial enterprises, was "the control and operation of human and material resources in order that the nation may be enabled to display its total power most effectively for the realization of national defense purposes in time of war." Main bank practices, for example, have been traced to wartime financing directives issued by the Ministry of Finance to the banking industry. And the impact of this regime appears to have been even more pervasive than the banking and finance scholars have indicated. A recent Japanese newspaper editorial suggests that the law "cast a spell" over Japan, serving as both catalyst for the economic dynamism of the 1980 s and albatross in the long recession of the $1990 \mathrm{~s}^{45}$

Important as these influences no doubt were, it is difficult to credit wartime production alone with shaping the corporate governance norms of the next half century. After all, the National General Mobilization Law was repealed fifty-five years ago. The Japan of the 1970 s to 1990 s bears little economic, political, or social resemblance to the Japan of the 1930s and 1940s. Two central insights from standard norm scholarship help enrich the scanty existing account of the emergence and persistence of Japanese corporate norms. First, norms can sometimes supply a governance framework at lower cost than formal rules. Second, norms are subject to strategic manipulation, including manipulation by the state. In the remainder of this Part, I draw on these insights to explain the rise and persistence of normative corporate governance in postwar Japan.

One of norm scholarship's principal contributions to date lies in showing that over a wide range of human activity, informal norms provide more efficient mechanisms to govern conduct than legal

12 See, e.g., Teranishi, supra note 35 , at 65-66, 75-80 (discussing the Japanese government's intervention into business during World War II and its effects on the postwar period).

Kokka sōdōinhō, Law No. 19 of 1938.

* Id. art. I.

4. Mitsuo Miura, Economic Forum: Breaking Free from Stranglehold of Wartime Regime, YOMIURI SHIMBUN, May 3, 2000. 
rules. ${ }^{46}$ Applying this insight to Japan, it is highly plausible that in the immediate postwar environment, nonlegal rules supplied a corporate governance framework at lower cost than the legal system. To understand why, consider the extant legal system as it impacted corporate conduct. Japan's Commercial Code, a late-nineteenth-century German transplant, was extensively amended in 1950 under the influence of the occupation reformers to imbue the law with American notions of shareholders' rights. Among other changes, the amended Code enabled shareholders to access corporate records, bring derivative suits, vote cumulatively, and receive share appraisals in mergers. In short, minority investor legal protections were enhanced in precisely the ways that modern reformers suggest is crucial for good corporate governance in transition economies. ${ }^{47}$ While the amendments eventually received support from the business community, academic and practitioner commentary was initially highly critical of the drastic increases in shareholder rights, ${ }^{48}$ which co-existed awkwardly with the Code's emphasis on creditor protections. A board of directors and concepts of director accountability were also introduced into the Code at this time. ${ }^{49}$ Yet the new board of directors overlapped with the Code's preexisting, German-style statutory auditor system, which was also designed to monitor corporate compliance. Thus, from its inception, the board was functionally orphaned by the statutory scheme.

Japanese securities laws also had been recently transplanted from abroad. The occupation reformers refused to reopen Japanese securities exchanges after the war until a statute resembling the U.S. securities laws was enacted. This was accomplished with the Securities Exchange Act of 1948, which is based heavily on the U.S. Securities Act of 1933 and Securities Exchange Act of 1934. The statute emphasizes investor protection and features a broad antifraud rule based directly

${ }^{46}$ The comparative advantages of private versus public ordering are a mainstay of the norm literature. See, e.g., Ellickson, supra note 2 (concluding that valuemaximizing norms, not law, are central to social order); Bernstein, supra note 2, at 157 (arguing that private dispute resolution in the diamond industry is superior to recourse to the legal system); Janet T. Landa, Personal Versus Impersonal Trade: The Size of Trading Groups and Contract Law, 4 INT'L REV. L. \& ECON. 15 (1984) (arguing that trade groups are a response to inefficient legal structures).

47 See infra Part IV.A.

${ }^{43}$ Mark D. West, The Puzzling Divergence of Comporate Law: Evidence and Explanations from Japan and the United States, 150 U. PA. L. REV. (forthcoming 2001), available at http://papers.ssrn.com/sol3/papers.cfm?cfid $=4286048$ ccftoken $=853932838$ abstract_id $=251028$.

${ }^{49}$ Id. 
on section 10 of the 1934 Act." An independent SEC-style agency was established to enforce the securities laws. ${ }^{35}$ As with the corporate law, however, the new securities laws rested uneasily with national sentiment and the creditor orientation of the corporate law. Important features of the new securities law regime, including the SEC-style agency, were either repealed as soon as the occupation ended or atrophied in the ensuing decades.

The bankruptcy regime-"a dislocated set of procedures that has developed haphazardly according to historical circumstance ${ }^{\$ 32}$-was similarly not conducive to efficient utilization. Some parts of the corporate reorganization regime are influenced by German law and date to the 1920s; other parts were added in the wake of the occupation and are modeled on U.S. law. In general terms, the problem is that some reorganization options differ little from a private workout (providing scant incentive to use the state's ground rules), while other options are so procedurally rigid as to be highly unattractive.

In view of the more recent transition economy experience, it is not surprising that this legal regime was overridden by private ordering and thus had little impact on corporate practices. Indeed, it would have been more surprising if Japan had somehow escaped the "transplant effect"-the inability of countries to assimilate foreign laws rapidly, particularly in the absence of smoothing agents such as a legal profession familiar with the new statutes. ${ }^{33}$ The transplant effect was all the more likely to occur in transitional Japan since enforcement of the rights and protections contemplated by the new statutes depended upon a small, newly independent judiciary with limited enforcement powers and a procedural landscape devoid of enforcement incentives for legal professionals.

In some areas, norms likely prevailed because state-set ground rules for economic activity were inadequately specified-a situation that persisted until very recently. The No Hostile Takeover norm pro-

On the origins of Japanese securities law, see Curtis J. Milhaupt, Managing the Market: Tho Ministry of Finance and Securities Regulation in Japan, 30 STAN. J. INT'L L. 423 (1994).

Id. at $432-33$.

Stacey Steele, Evaluating the New Japanese Civil Rehabilitation Law, 2 AUSTRAzIANJ. ASLIN L. 53, $56(2000)$.

The transplant effect has most recently afflicted the transition economies of Eastern Europe. Set Daniel Berkowitz et al., Economic Development, Legality, and the Transplant Effect 4 (Nov. 1999) (unpublished manuscript, on file with Social Science Research Network), available at http://papers.ssrn.com/sol3/papers.taf?cfid= 42860 \& 8 cftoken $=85393283 \&$ abstract_id $=183269$. 
vides an informative example. Until 1990, there were no share ownership disclosure requirements under the securities laws. Thus, it was possible for a raider or greenmailer to secretly amass shares of a public company and spring itself upon an unsuspecting management. Procedural safeguards in tender offers as well as securities antifraud rules remained underdeveloped through the 1980s. To this day, the Commercial Code provides managers with little flexibility to craft defensive measures to fend off unsolicited bids. In such an environment, a social norm denigrating hostile takeovers as unethical could operate as a low-cost substitute for an extensive system of formal ground rules for M\&A activity and as a complement to the structural obstacle posed by cross-shareholding practices. Even if the norm is superfluous in those roles, it may have emerged as a convenient and self-serving shorthand for a complex institutional reality. Alternatively, it may persist largely as a historical vestige of an era (particularly before the rise of cross-shareholding) when it did play a role in dampening takeover activity.

Standing alone, however, the explanation from transaction cost economizing confronts both empirical and theoretical problems. While the Japanese legal and economic environments have evolved significantly since the occupation, the nonlegal rules emerging in the immediate postwar period continued to pervade the corporate governance regime. Most acutely, explanations from efficiency alone fail to account for the past decade, in which Japanese firms and banks adhering to the norms have lost international competitiveness (see Table 1). Theoretically problematic is the assumption that dispersed actors sustained, for many decades, a high degree of coordination in the face of a collective action problem. While it is collectively rational for each of the players of Japanese corporate governance to continue adhering to the norms if the per-firm benefit to the economy of private ordering exceeds the per-firm cost, it is individually rational for each firm to defect from those norms where the gains from launching a hostile takeover or failing to rescue a troubled borrower, for example, exceed the firm-specific benefits of norm compliance. This analysis suggests that normative corporate governance would not be a stable equilibrium unless (1) the postwar norms were immediately and universally internalized, (2) a coordination mechanism exists, or (3) there are substantial private benefits to norm compliance. 


\section{Table 1: Japan's World Competitiveness Ranking 1986-2000}

\begin{tabular}{|c|c|}
\hline $1986-1993$ & 1 \\
\hline 1994 & 3 \\
\hline 1995 & 4 \\
\hline 1996 & 4 \\
\hline 1997 & 9 \\
\hline 1998 & 18 \\
\hline 1999 & 16 \\
\hline 2000 & 17 \\
\hline
\end{tabular}

Thus, in order for our explanation to be complete, we need an account not only of the creation of the norms, but also of their persistence despite changes in the transaction cost environment and evidence of their eventual inefficiency. I discount the rapid internalization of the new norms as an explanation because no convincing theory exists to explain such a phenomenon. Rather, two causes of inefficient norm persistence seem particularly relevant to our account. $^{53}$ First, information lags bedevil the efforts of any group to maintain efficient norms in the face of changing environments and technologies. Even if old norms are gradually replaced, the inefficient norm governs during the transition period. As Table 1 suggests, the deterioration in Japanese productivity was precipitous. Perhaps not surprisingly, early signs of inefficiencies in normative corporate governance were dismissed as aberrational and the system veered perilously close to collapse before norm reform began in earnest.

Second and perhaps more importantly, norms may be created and maintained for the private benefits they provide to favored groups. The circumstantial evidence of norm capture in Japan is compelling. World War II and its aftermath destroyed many organized interest groups in Japan. ${ }^{30}$ Several groups, however, including the bureaucracy

INT'L INST. FOR MGMT. DEV., WORLD COMPETITIVENESS REPORT (various years); INT'L INST. FOR MGMT. DEV., WORLD COMPETITIVENESS YEARBOOK (various years). In citing these rankings, I am conscious of the criticism directed at the notion of "world" or "international competitiveness." See, e.g., PAUL KRUGMaN, POP INTERNATIONALISM 10 (1996) (suggesting that the term is misleading and simply another way of saying "productivity"). Even if the term is open to criticism, the rankings are illustrative of the deterioration in Japan's productivity vis-à-vis that of other countries.

See, e.g., Eric A. Posner, Law, Economics, and Inefficient Norms, 144 U. PA. L. REV. 1697, 1711-19 (1996) (discussing information lags and strategic behavior as causes of inefficient norms).

MaNCUR Olson, THe Rise AND DeCline OF NATIONS 75-76 (1982). 
(particularly the Ministry of Finance), leaders of major commercial banks, and corporate managers of the former zaibatsu, not only survived the occupation intact, but by design or serendipity actually enjoyed enhanced power as a result of the political and economic purges. $^{37}$ Whatever initial comparative advantage norms may have enjoyed over legal rules in postwar Japan, the norms of Japanese corporate governance also clearly benefited the interest groups left standing after the occupation. As Mark Ramseyer has argued, a no-takeover ideology benefits managers of large corporations both by insuring them against economic losses in a takeover and by justifying managerial power. ${ }^{58}$ The norm on board role and structure, with its selfserving emphasis on employee loyalty and the exclusion of outsiders, performs a similar role. The main bank system allowed large banks to extract rents from their borrowers. ${ }^{59}$ Financial regulators, in turn, benefited from enhanced discretion and public prestige accruing to the managers of a highly informal financial system that avoided bank failure. More tangibly, they also derived rents from banks in the form of a highly institutionalized system of lucrative post-retirement employment opportunities with regulated firms.

Normative corporate governance can thus be viewed as a largely self-enforcing, informal response to the postwar legal environment. Crucially, because powerful governmental actors also derived private benefits from norm compliance, there was a built-in coordination mechanism to overcome the collective action problem. The norms were relatively impervious to change, despite their eventual inefficiency for society as a whole, because they continued to generate significant private benefits to powerful groups.

${ }^{37}$ The occupation authorities chose to rule through the bureaucracy, in particular the Ministry of Finance, insulating it from major reform. The economic purge of wartime executives and breakup of powerful "city" banks closely allied with zaibatsu were either abandoned or diluted as reverse-course policies gained ascendance in the years following Japan's surrender. JOHN W. DOWER, EMBRACING DEFEAT: JAPAN IN THE WAKE OF WORLD WAR II 532-33, 544-45 (1999). Ironically, the dissolution of the zaibatsu actually reinforced the rights of corporate insiders by creating the ideal conditions for a pure internal promotion system insulated from both family succession problems and outside directors. Fabrizio Barca et al., Post-War Institutions: The Divergence of Italian and Japanese Corporate Governance Models 23-24 (1998) (unpublished manuscript, on file with author).

${ }_{58}$ Ramseyer, supra note 14 , at 12-13.

${ }^{59}$ David E. Weinstein \& Yishay Yafeh, On the Costs of a Bank-Centered Financial System: Evidence from the Changing Main Bank Relations in Japan, 53 J. FIN. 635, 639 (1998). 


\section{B. The Interaction of Corporate Norms and Law}

Not suprisingly, heavy reliance on nonlegal rules reduced demand for corporate law and legal professionals in postwar Japan. The main bank system redirected some of the most complex corporate reorganizations away from the legal system, replacing the judge and courtappointed receiver in a formal bankruptcy proceeding. ${ }^{60}$ The main bank system also provided a substitute for the accountants and credit rating agencies who specialize in corporate monitoring and disclosure for the benefit of corporate claimants in more capital-market-driven financial systems.

Similarly, private ordering provided substitutes for legal procedures designed to protect shareholder rights. The concentration of large blocks of stock in the hands of banks and other institutional investors and the organization of many firms into keiretsu corporate groups with a main bank at the center provided mechanisms of voice and access to information for many Japanese institutional shareholders that were less costly and more effective than Commercial Code mechanisms. This was particularly true because, until recently, procedural requirements made shareholder derivative litigation very costly."

Norms were also used to bypass roadblocks in the legal system for investor protection. As noted above, Japanese securities law contains a broad antifraud provision facially similar to Rule $10 \mathrm{~b}-5 .{ }^{62}$ Yet, in contrast to the situation in the United States, the Japanese provision is the basis of no private securities fraud litigation (and virtually no public enforcement either, at least until very recently). The ostensible legal reason is prosaic: the antifraud provision does not expressly contemplate suits by private claimants, and Japanese courts do not recognize implied private rights of action. The normative response was creative: instead of suing, aggrieved investors relied on an informal norm in

in To be sure, rapid economic growth in the 1970 s and 1980 s kept the number of corporate reorganizations low in any event.

i. Japanese law contains a shareholder derivative suit mechanism, which was adopted in 1950 and is similar to that found in U.S. state corporate codes. Shareholders who satisfy minimal standing requirements can bring suit against directors for breach of duty. Yet until recently, this mechanism was virtually moribund in Japan. Derivative suits were rare because enforcement problems raised the cost of the procedure relative to private alternatives. Until a statutory amendment in 1993, most Japanese courts held that the amount of the filing fee required to initiate such a suit should be tied to the amount in controversy. This posed a formidable barrier to litigation, since the damages sought in derivative suits are often substantial.

". Supra text accompanying notes 50-51. 
the securities industry under which large brokers implicitly indemnified important customers for investment losses. ${ }^{63}$ In order to seek redress for losses in securities transactions, investors began turning to the courts in large numbers (claiming breach of contract or tortious injury) only after this practice was prohibited in the early 1990s.

Table 2 provides data on the demand for law in the governance of Japanese firms. While the measurement is imperfect, Table 2 highlights the traditional infrequency of direct resort to the standard legal mechanisms for resolving disputes and organizing relations among shareholders, managers, and creditors. It is of course both possible and likely that the legal regime nonetheless affected private ordering. It also bears noting that resort to these mechanisms is becoming more routine, a development that is explored in the next part of the Article.

\section{Table 2: Demand for Corporate Law ${ }^{64}$}

\begin{tabular}{|l|c|}
\hline $\begin{array}{c}\text { Number of Tender Offers for Public Companies } \\
\text { 1971-1999 }\end{array}$ & 51 \\
\hline Number of Shareholder Derivative Suits Filed 1950-1990 & 23 \\
\hline $\begin{array}{c}\text { Number of Private Securities Fraud Cases Brought } \\
\text { Under the Securities Exchange Law 1950-2000 }\end{array}$ & 0 \\
\hline $\begin{array}{c}\text { Average Annual Number of Griminal Cases Brought Un- } \\
\text { der the Securities Exchange Law 1989-1998 }\end{array}$ & 3 \\
\hline $\begin{array}{c}\text { Percentage of Corporate Insolvencies Resolved } \\
\text { Through the Legal System 1980-1990 }\end{array}$ & 10 \\
\hline
\end{tabular}

The process of Commercial Code reform in Japan also indicates an historically sluggish demand for corporate law. Traditionally, most corporate law reforms were not the result of competitive or even interest group pressures, as private actors sought a more efficient or privately beneficial formal governance framework. Rather, changes were prompted by one of two impulses. Some were theoretically appealing

${ }^{63}$ Milhaupt, supra note 50, at 460 .

${ }^{64}$ Data on tender offers are from Keisho Komoto, The Present Status of Takeover Bids (TOB) and Their Effect on Stock Prices, 147 NLI RESEARCH 8 (2000), and Kanda, supra note 13, at 934; data on shareholder derivative suits are from 196 BESSATSU SHōjl HŌMU 475-82 (1997); data on securities fraud cases by regulators are calculated from SHIHŌ TOKEI NEMPŌ [ANNUAL OF JUDICIAL STATISTICS] (various years); data on insolvencies are calculated from Frank Packer \& Marc Ryser, The Governance of Failure: An Anatomy of Corporate Bankruptcy in Japan 57 tbl.1 (1992) (unpublished manuscript, on file with the Columbia University School of Business, Center on Japanese Economics and Business). 
revisions made by the scholars and Justice Ministry officials in charge of Commercial Code reform ("theory pushed" rather than "demand pulled" reforms in the words of one scholar ${ }^{65}$ ); others were responses to exogenous shocks such as political scandals. ${ }^{6 \hat{6}}$ For this reason, throughout postwar Commercial Code history, many legal reforms have had little or no effect on Japanese corporate practices. ${ }^{67}$ Only the small number of recent demand-pulled reforms discussed in Part III of this Article have led to significant changes in practice.

At least partly as a result of the substitution effect between private and public ordering, as Table 3 indicates, Japan has the smallest formal legal system of any major industrialized country. Table 3 must be interpreted with considerable care, because it understates the size of the Japanese lawyer population in failing to include significant numbers of quasi-legal professionals and an even larger number of lawtrained public and private sector employees who perform lawyer-like tasks. Notwithstanding this caveat, however, Japan has only about 1000 corporate and securities lawyers as those terms would be understood in the United States. The Japanese legal system is small even in comparison to the German and French legal systems, which served as models for Japan during its first modern phase of legal transplanting. Particularly noteworthy is the small number of judges in Japan.

Shishido, supra note 38 , at 9 .

"West, supra note 48 .

"17 Shishido, supra note 38 . 
Table 3: International Comparison of Judicial Systems $(1997)^{\text {is }}$

\begin{tabular}{|c|c|c|c|c|c|}
\hline & U.S. & England & Germany & France & Japan \\
\hline $\begin{array}{c}\text { Legal Pro- } \\
\text { fession }\end{array}$ & 940,508 & 82,653 & 111,315 & 35,695 & 19,733 \\
\hline $\begin{array}{c}\text { Per 100,000 } \\
\text { Population }\end{array}$ & 352.5 & 158.3 & 135.7 & 61.3 & 15.7 \\
\hline Lawyers & 906,611 & 80,868 & 85,105 & 29,395 & 16,368 \\
\hline $\begin{array}{c}\text { Per 100,000 } \\
\text { Population }\end{array}$ & 339.87 & 154.89 & 103.77 & 50.15 & 13.0 \\
\hline Judges & 30,888 & 3170 & 20,999 & 4900 & 2093 \\
\hline $\begin{array}{c}\text { Per 100,000 } \\
\text { Population }\end{array}$ & 11.6 & 6.07 & 25.6 & 8.4 & 1.7 \\
\hline
\end{tabular}

\section{Evaluation}

The process I have described is a mutually reinforcing cycle. The formal institutional environment is problematic, leading those with the most at stake to generate alternative practices. Powerful interest groups (including some state actors) select norms consistent with their own self-interest. A process of what might be called "social codification" occurs as the favored groups become contented with the informal institutions and memories of inconsistent practices fade. Pervasive resort to norms reduces demand for law and legal reform. Lack of competition from the legal system, in turn, contributes to the durability of the norms.

While the norm literature recognizes complementarities between public and private ordering, scholars have focused attention almost exclusively on the "expressive function" of law. Similarly, it is now well understood that the state can draw in more private enforcement of a norm by enacting it into law. ${ }^{69}$ Indeed, we saw an example of this in lifetime employment, where the courts confirmed and diffused a social norm in favor of employment security. ${ }^{70}$ But Japan's experience demonstrates that the state also reinforces norms by simply failing to

${ }^{68}$ Saikö Saibansho [Supreme Court of Japan], 21-Seiki no shihō seido w'o kangauru [On the Legal System of the 21st Century] tbl.16 (2000), http://www.courts.go.jp/ pre21/16.gif.

${ }^{69}$ See Robert D. Cooter, Law from Order: Economic Development and the Jurisprudence of Social Norms, in A Not-So-DisMal SCIENCE 242 (Mancur Olson \& Satu Kähkönen eds., 2000) (stating that the backing of state officials increases the effectiveness of private enforcement and lowers its costs).

${ }^{70}$ See supra Part I.D. 
mobilize its lawmaking power against them. To be sure, the state actively promoted normative governance by directly supporting the payoffs from norm compliance and by occasionally serving as enforcer of ostensibly private commitments. The operation of the main bank system is perhaps the best example of the government's overt role in norm enforcement.

More subtly, however, the state exercised its monopoly power over the legal system to raise the cost of norm deviation. ${ }^{71}$ For example, the Lifetime Employment norm may have been less stable if the government had not strictly regulated headhunting. ${ }^{72}$ The No Hostile Takeover norm and belief system about corporate boards were buttressed by low-quality corporate and financial disclosure..$^{73}$ More firms may have used the tender offer process for both friendly and hostile deals in a more robust environment for financial disclosure, since lack of information is a serious obstacle to corporate acquisitions. Similarly, boards of directors may have become more attuned to monitoring and shareholder accountability under a more stringent disclosure regime, particularly if costly procedural barriers to derivative litigation had been removed more promptly. As the next section of the Article shows, these norms began breaking down rapidly once their inefficiency was publicly revealed.

The Japanese experience also casts light on a mainstay of the norms literature: the debate over the comparative advantages of public versus private ordering. The question is whether norms or law should be preferred as a tool of social governance. Jonathan Macey, for example, has asserted a categorical public-choice-based preference for private ordering, on the ground that legal rules exist where norms

"This inertial approach to norm reinforcement is particularly effective in systems like Japan's that adhere to a norm of regulatory prohibition. This is a shared social under tanding among regulated groups that conduct not explicitly approved by law is prohibited. Hideki Kanda, Politics, Formalism, and the Elusive Goal of Investor Protection: Rrgulation of Structured Investment Funds in Japan, 12 U. PA. J. INT'L BUS. L. 569, 582 (1991). While adherence to the norm lowers the cost of lawmaking, it also greatly reduces private innovation around inefficient rules-and inefficient norms to the extent they would otherwise be eroded by new law-or channels that innovation into corruption or organized criminal activity. See Curtis J. Milhaupt \& Mark D. West, The Dark Side of Privat Ortming: An Institutional and Empirical Analysis of Organized Crime, 67 U. CHI. L. REV. $41,+3$ (2000) (arguing that organized crime is "the dark side of private ordering-an entrepreneurial response to inefficiencies in the property rights and enforcement framework supplied by the state").

T: Gilson \& Roe, supra note 27, at 527-28.

"Ser Richard H. McAdams, The Origin, Development, and Regulation of Norms, 96 MICH. L. REV. 338, 392 (1997) (noting that "law can manipulate norms by manipulating information"). 
alone would be suitable because organized groups demand laws from politicians. ${ }^{74}$ Other scholars have voiced suspicion that norms will usually not be fully efficient, because they arise in situations that depart from the classic model of perfect competition. ${ }^{75}$ In the Japanese case, norms did provide a comparatively efficient governance structure when the legal framework for corporate conduct was unfamiliar, incomplete, and weakly supported with enforcement incentives. But Japan's experience suggests that the converse of Macey's claim can also be true: norms may persist where legal rules would be more efficient due to the same capture phenomenon that is well understood in the regulatory context.

One of the reasons Japan's ongoing recession has been so prolonged and severe is that norms had to be undermined before elements of the legal framework critical to recovery could be erected. This was most apparent in banking, where a legal structure for handling bank failures had to be built virtually from scratch before any progress could be made toward resolving the nonperforming loan problem. Before the political process could be engaged to create such a structure, however, the underlying social norms that aggrandized the No Failure principle for banks (and thus precluded the operation of market forces in the banking industry) had to be undermined. ${ }^{76}$

\section{CREATIVE NORM DESTRUGTION}

Despite their tenacity, the postwar norms of Japanese corporate governance are being destroyed by a confluence of forces. 'Norm reform is taking place for the reasons predicted in the models developed by norm scholars: ${ }^{77}$ exogenous shocks are altering cost-benefit conditions and group membership, increased information is giving

${ }^{74}$ Jonathan R. Macey, Public and Private Ordering and the Production of Legitimate and Illegitimate Legal Rules, 82 CORNELL L. REv. 1123, 1124 (1997).

${ }^{75}$ Avery Katz, Taking Private Ordering Seriously, 144 U. PA. L. REv. 1745, 1749 (1996). Katz is careful to add, however, that because state-set norms may suffer from the same limitations, a priori there is no basis for preferring public or private lawmaking.

See Curtis J. Milhaupt, Japan's Experience with Deposit Insurance and Failing Banks: Implications for Financial Regulatory Design?, 17 MONETARY \& ECON. STUD. 21, 23 (1999) [hereinafter Milhaupt, Deposit Insurance].

${ }^{77}$ See Robert C. Ellickson, The Evolution of Social Norms: A Perspective from the Legal Academy 7 (July 1999) (unpublished manuscript, on file with Social Science Research Network), available at http://papers.ssrn.com/sol3/papers.cfm?cfid= 428604 \&cftoken $=85393283 \&$ abstractid $=191392$. 
rise to norm shopping, agents specially suited to lead the process of norm change are emerging, and state actors are engaging in norm manipulation. I take up the process of norm reform for each of the nonlegal rules examined above.

\section{A. Main Bank Norms}

The norms supporting the operation of the main bank system have been under stress for most of the past decade. A complete appreciation of their gradual demise would require recounting the bubble economy, the ensuing banking crisis, and the tortured efforts to build a viable financial regulatory structure in Japan, a task that I will not undertake here. ${ }^{78}$ Instead, I wish to highlight three developments that are destroying the main bank norms as traditionally understood: (1) a change in the economics of the operation of these norms, (2) a shift in belief systems about bank governance and corporate governance, and (3) a quirky exogenous shock that delivered a blow to the norms at the heart of the main bank system.

The first step in the destruction process is a dramatic change in the payoff structure to banks that abide by the main bank norms. For most of the postwar period, there was a compelling economic logic to the main bank system. Banks delegated monitoring and restructuring responsibilities for a given firm to its main bank, which possessed superior information about the firm's operations and prospects. As noted above, main banks were willing to perform this role at least in part because they extracted rents from their borrowers. ${ }^{79}$ In turn, the importance of the main bank institution to the economy insulated banks from failure and ensured a steady stream of regulatory rents, which provided incentive to continue behaving as a "good" main bank.

This logic began to unravel, however, when the moral hazard implicit in the main bank norms peaked in the bubble period of the 1980 s, resulting in a massive nonperforming loan problem. By the mid-1990s, the international financial community began to perceive an unusual form of systemic risk arising from the norm-supplied safety net. While not expressed precisely in these terms, the market worried

\footnotetext{
${ }^{7 *}$ For analysis, see Milhaupt, Deposit Insurance, supra note 76; Milhaupt \& Miller, supra note 12.

Weinstein \& Yafeh, supra note 59, at 639.

"Takeo Hoshi \& Hugh Patrick, The Japanese Financial System: An Introductory Overvieu, in CRISIS AND CHANGE IN THE JAPANESE FINANCLAL SYSTEM, supra note 32 , at 1,7 .
} 
that regulators would undermine the strength of major Japanese banks by enforcing the Equitable Subordination norm-that is, pressuring the banks to bear more than their pro rata share of losses in connection with the collapse of weak institutions to which they had lent heavily-and by enforcing the No Failure norm by orchestrating acquisitions of institutions that should have been allowed to fail. The price exacted for these concerns was labeled the "Japan Premium," an additional risk premium charged by non-Japanese banks on loans to Japanese banks in international money markets. At one time the Japan Premium exceeded 100 basis points (one percent), a large premium given the razor thin margins in this area of finance. Crucially, until a major Japanese bank was allowed to fail in late 1997, the same premium was charged to all Japanese banks regardless of individual financial strength, a clear indication that the premium reflected systemic risk arising from the implicit regulatory scheme. ${ }^{81}$

The second step in the destruction of the main bank norms is a significant shift in beliefs about the benefits of bank-oriented corporate finance and governance. Not long ago, Japan was a model for developing economies in Asia and Eastern Europe. In contrast to the United States, Japan had not politically hamstrung large financial intermediaries from playing a role in corporate governance. Banks solved agency and information problems inherent in stock market driven systems, led to far-sighted alliances between capital and production, and served as pliant partners of government in carrying out industrial policy (or so the argument went). But in the wake of the Asian financial crisis and Japan's long recession, "relationship financing" became "crony capitalism." Easy credit policies inherent in bankoriented systems are now linked with monitoring lapses and poor corporate performance. ${ }^{82}$

The third and perhaps most interesting step in the destruction of main bank norms is the nationalization and reprivatization of the Long-Term Credit Bank ("LTCB"), one of postwar Japan's largest and most politically connected banks. LTCB, which served as the main bank for many important firms, became insolvent and was temporarily nationalized in 1998. It was later sold to Ripplewood, a group of foreign investors including Citigroup and GE Capital, when no Japanese

${ }^{81}$ Milhaupt, Deposit Insurance, supra note 76; Milhaupt \& Miller, supra note 12.

82 See, e.g., Anderson \& Campbell, supra note 8, at 1 (finding that ineffective governance exacerbated the Japanese banking crisis and delayed restructuring); Randall Morck \& Masao Nakamura, Banks and Corporate Control in Japan, 54 J. Fin. 319, 319-20 (1999) (reassessing the efficacy of Japanese bank governance of firms). 
buyer for the bank could be found. The acquisition agreement gave Ripplewood the option to return to the government any assets (loans) that decline from March 1, 2000 book value by twenty percent or more within three years. The put option is lost, however, if the bank (renamed Shinsei Bank) accepts a borrower's request for loan forgiveness.

Whether intended by the government or not, by altering the bank's incentive structure in this way, the Shinsei deal threatens the bank's nonlegal commitment to failing borrowers. Since loan forgiveness is a central feature of the main bank system as traditionally understood, the agreement undermines a crucial informal rule in Japanese finance. Indeed, in several recent cases, including the high profile bankruptcy of Sogo Department Store, Shinsei refused requests to write off loans to failing borrowers, leaving the firms no choice but to resort to legal protection under the bankruptcy regime. ${ }^{n . t}$ This prompted a Japanese newspaper to grouse that the bank had "ignored traditional Japanese thinking by rejecting a plan to forgive Sogo's debts." As a result, Shinsei's status as a main bank, and the continued viability of the norm-based main bank institution itself, are in question." Standard \& Poor's, for example, recently noted "increasing uncertainties over the system of credit support for major Japanese companies, which many Japanese borrowers and lenders had taken for granted." "sii The report concludes that "[t] he long-held perception ... that major Japanese companies are too big to fail is no longer valid."

Riborn LTCB Has a Western Look, NIKKEI WKLY., June 12, 2000, available at http://ptg.djnr.com/ccroot/asp/publib/story.asp.

"Analysis: Sogo's Collapse May Bring About New Financial Order, YoMIURI SHIMBUN, July $19,2000$.

Analysi: Slinsei Bank Carries a Heavy Burden of LTCB Legacy, YOMIURI SHIMBUN, June 7, 2000 (quoting one bank executive as stating, "[i]t has become difficult to see Shinsei Bank playing the role of a main bank"). Some in the industry suggest that if Shinsei is unvilling to forgive debts, it will be excluded from the Japanese banking community and will need to rely on foreign capital. Id. This refers to the fact that LTCB did not rely on deposits for capital, but instead raised funds by issuing debentures to Japanese institutional investors.

"Jitendra Joshi, Dangers Grow for Japan Inc.'s Credit Quality: Standard and Poor's, AGENCE FRANCE-PRESSE, July 18, 2000.

${ }^{\prime}$ Gillian Tett, Japanese Haunted by Turmoil of '98, Fin. TIMes, July 20, 2000, at 25, available at http://globalarchive.ft.com/globalarchive/articles.html?id=000720000260 \&query=gillian+tett. Shinsei is not the only bank playing by new rules. Other major Japanese banks refused to extend debt forgiveness programs to a real estate group, which was forced to file for liquidation. 


\section{B. The No Hostile Takeover Norm}

Looking back, scholars may date the beginning of the end of the No Hostile Takeover norm to January 24, 2000. On that date, a Japanese firm called M\&A Consulting, Inc. ("MAC") launched a hostile tender offer for Shoei Corporation, a member of the Fuyo keiretsu. This was one of the first postwar hostile takeover bids for a Japanese corporation by a Japanese corporation.

The bid was motivated by a desire to destroy the No Hostile Takeover norm. ${ }^{88}$ This is evident from the nature of the offer itself and from MAC's own public pronouncements. For example, although the market price of Shoei shares quickly reached and then surpassed the offering price of $¥ 1000$ per share (a fourteen percent premium over Shoei's closing price on the day prior to the offer), MAC steadfastly refused to raise its bid. Even in the midst of the offering period, the bidder's CEO publicly admitted that he never expected to win a controlling stake in Shoei because Fuyo group companies owned approximately sixty percent of its shares and were unlikely to tender them in the bid. ${ }^{89}$

MAC's own publicity materials emphasize its norm reform mission. The materials stress that the firm is "[n]ot bound by conventional ideas and practices." They describe MAC as "an active market player that is making its mark on corporate Japan." "The company professes a "Firm Belief in the Market Economy" and views "M\&A as one of the powerful tools for dynamic restructuring."

What makes the bid even more interesting is the man behind it. The CEO of MAC is Yoshiaki Murakami, formerly a senior official at the Ministry of International Trade and Industry ("MITI"), traditionally one of the most elite positions in Japanese society. Murakami is a textbook example of what Robert Ellickson calls a change agent. Change agents are low-cost suppliers of new norms because they pos-

${ }^{88}$ At least this was the primary purpose of the bid as represented to me by one of the principals. Interview transcript I (Tokyo, June 27, 2000). This is not to say that the motives of the bidder were purely altruistic. Indeed, as explained below, the bidder had reason to expect both tangible and intangible benefits from a breakdown in the norm. See infra text accompanying notes 9498 .

${ }^{89}$ Peter Landers, First Japanese To Seek Hostile Takeover Expects To Fall Short, Seek Board Seat, WALL ST. J., Feb. 11, 2000 , at Al2.

${ }^{90}$ Introduction to M\&A Consulting (June 2000) (unpublished materials, on file with author).

${ }_{92}$ Id.

${ }^{92} \mathrm{Id}$. 
sess attributes such as technical knowledge and leadership skills that reduce the opportunity costs of norm reform. Moreover, change agents can anticipate both tangible and intangible benefits from the acceptance of the new norm. More specifically, Murakami displays both of the traits Ellickson identifies with the "norm entrepreneur," a subspecies of change agent. First, Murakami "possess[es] a relatively high level of technical knowledge relevant to the norms within his specialty." At MITI, Murakami spent much of his career on industrial policy, corporate governance, and M\&A issues. He was thus intimately familiar with the legal and social institutions surrounding Japanese M\&A. Second, he "is likely to be cognizant that there are appreciative experts (often, close associates in a social subgroup) who are likely immediately to esteem the norm entrepreneur for trying to change the social practice at issue." Murakami's efforts were generally applauded in the Japanese and foreign financial press, ${ }^{95}$ the legal and investment banking communities, ${ }^{96}$ and by his former colleagues at MITI, where corporate governance reform is now a major preoccupation." Whether Murakami anticipated such widespread applause is unknowable. Yet Murakami has long-standing political ambitions, ${ }^{98}$ and at the very least he may have anticipated a major boost in name recognition as a result of his norm reform effort. More tangibly, he saw a business opportunity as a consultant in a robust market for corporate control.

The bid was financed by Orix Corporation, a leasing and financial services company that is viewed in Japan as a corporate nonconformist." The CEO of Orix, Yoshihiko Miyauchi, played a supporting role

"s Ellickson, supra note 77, at 19.

"Id

"See, e.g., Nihon sho "Tettaiteki baishü", [The Meaning of Japan's First "Hostile Acquisition ], NIHON KEIZAI SHIMBUN, Jan. 27, 2000, at 3 ("Although it is a mini-deal by world standards, [MAC's bid for Shoei] is a fitting way to begin the year 2000 for Japan, a runner that is being lapped in the race among capitalist countries."); Peter Landers, $A$ Hostile Takeover Bid Elbows Its Way into Usually Polite Japan, WALL ST. J., Jan. 25, 2000, at Al3 ("[T] he struggle for Shoei could become a milestone in Japanese corporate history.").

"tt" Interview Transcript B (Tokyo, June 20, 2000); Interview Transcript $\mathrm{H}$ (Tokyo, June 27, 2000); Interview Transcript $K$ (Tokyo, June 27, 2000). Most lawyers and investment bankers did see shortcomings in the Shoei bid as a precedent, however, given its small size and failure to attract keiretsu shareholders.

Interview Transcript M (Tokyo, June 28, 2000).

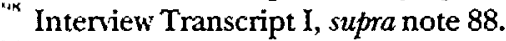

"** Phred Dvorak, Japan's Orix Burnishes Its Reputation as Maverick by Bankrolling Hostile Bid, WALL ST.J., Jan. 27, 2000, at A16 ("Orix group... is known for playing outside the rules that traditionally governed corporations."). 
in the cast of norm entrepreneurs. He is described by the Wall Street Journal as "a well-known advocate of shareholder rights and deregulation." One Japanese banker, reflecting on Orix's support for Japan's most highly publicized hostile bid, commented, "That's the type of thing Orix would do. Big Japanese banks wouldn't dare-they worry too much about what others would think." ${ }^{101}$

As expected, the bid failed when the Fuyo group companies refused to tender their shares. Ultimately, MAC increased its stake in Shoei by just a few percent. But this did not stop Murakami from claiming victory. On this point, he may have been correct. By many accounts, this small, quixotic, and unsuccessful bid helped tenderize the market for corporate control in Japan. ${ }^{102}$

\section{Board Role and Structure}

Professor Melvin Eisenberg has written perceptively about the normative underpinnings of the increased level of directorial care in the United States over the past decade. Eisenberg argues that because neither an increase in the threat of liability nor the prospect of gain can account for this change, the increased level of care must be due to a shift in social norms about the board's obligations. ${ }^{103}$ Ultimately, he traces this norm shift to a change in the belief system of the business community about the board's duty of care, functions, and structure. Corporate governance has changed over the past twenty years as the dominant conception of the board moved from a managerial model to a monitoring model. ${ }^{104}$ In Eisenberg's view, this change in belief system was due to new information about managerial efficiency that was transmitted by takeover premiums. The legal system reinforced the shift, as a series of Delaware cases created a new image of the board's proper role in corporate governance. ${ }^{105}$

The process that Professor Eisenberg describes for American boards has parallels in many recent developments in Japan. A significant shift in mindset-or at least rhetoric-among boards of major Japanese corporations is apparent, with the managerial model being

${ }^{100}$ Landers, supra note 95.

101 Phred Dvorak, Orix Takes a Maverick Stance in Japan, ASIAN WALL ST. J., Jan. 27. 2000 , at 1 (internal quotation omitted).

${ }^{102}$ See Interview Transcript K, supra note 96; Interview Transcript M, supra note 97.

${ }^{103}$ Eisenberg, supra note 1, at 1266-71.

${ }^{104} I d$. at $1278-82$.

${ }^{105} I d$. at $1269-71,1278-82$. 
replaced by the monitoring model. Consistent with Eisenberg's analysis of the U.S. situation, the threat of liability or prospect of gain is not sufficient to account for the heightened concern for corporate performance among Japanese managers. Until a major decision involving the directors of Daiwa Bank was rendered in the fall of 2000, the only cases in which directors of public companies had ever been found liable to their shareholders for breach of the duty of care involved unambiguous violations of domestic law, such as violations of the Commercial Code. ${ }^{106}$ The Daiwa Bank case itself, which involves a Caremark-like failure-to-monitor claim, represents egregious directorial nonfeasance regarding violations of foreign (U.S.) law. ${ }^{107}$ Thus, for all but a tiny fraction of Japanese directors, the threat of personal liability is small. Nor is increased income from enhanced performance likely to be the principal motivation for the change in mindset. Stock price, while a factor in executive compensation in Japan, does not have the high-powered incentive effects on management that it does in the United States because stock options are a very recent and limited component of executive compensation. Rather, Japan's waning international competitiveness and the stream of negative publicity surrounding managerial performance in the bubble period appear to have motivated the shift in beliefs about the directors' role.

While the threat of liability alone may not have been a rational reason to reshape the board's structure and function, the Japanese courts are helping to catalyze the change in directorial mindset. In the process of deciding a rash of shareholder derivative litigation that broke out when procedural barriers were removed in 1993, the courts are educating directors about the scope and content of their obligations. These cases have focused a spotlight on board conduct and, for the first time, put some interpretive flesh on the Commercial Code's skeletal description of directorial duties to the corporation.

The Daiwa Bank case is perhaps the best example of this process. Shareholders of Daiwa Bank derivatively sued eleven current and former directors for failing to uncover and report to U.S. authorities massive unauthorized trading in the New York branch that resulted in almost $\$ 1.5$ billion in losses and fines. When eleven years of unauthorized trades were finally revealed by the rogue trader's confession,

"'". HIDE. LKI KUBORI ET AL., TORISHIMLARTAKU NO SEKININ: DAIHTō SOSHŌ JIDAI NO RISL'KU KINRI [THE LLABILITIES OF DIRECTORS: RISK MANAGEMENT IN THE AGE OF SHLREHOLDER DERTATIVE LITIGATION] 102 (1999).

[1'7] Nishimura v. Abekawa (The Daiwa Bank Case), 199 SHIRYōBan SHōjı HōMU 248 (D. Ct., Sept. 20, 2000). 
senior bank management reported the problem to Japan's Ministry of Finance. The Ministry suggested that disclosure to the Federal Reserve, which had jurisdiction over the branch, be delayed to avoid instability in the Japanese financial system. Acting at the Ministry's suggestion, Daiwa filed a misleading Call Report with the U.S. banking regulators. When the Federal Reserve eventually discovered the problem, it fined the bank $\$ 340$ million and revoked the bank's license to operate in the United States. The Osaka District Court found the directors liable for breach of duty, and ordered them to pay about $\$ 775$ million in damages. In a passage that nicely illustrates the tension between old and new rules governing Japanese managers, the court found that "the defendant [directors] had persisted in following informal local rules that only apply in Japan, despite the fact that [the firm's operations] had expanded on a global scale." ${ }^{108}$

As educators of management, the Japanese courts are performing a modest version of the role Professor Edward Rock described for the Delaware courts. ${ }^{109}$ While the Japanese case law does not explicitly reference Delaware jurisprudence, it is hard to imagine that the courts (and by extension boards of directors) are not influenced by it. Virtually every scholarly analysis of the Japanese board's role in corporate governance now refers to landmark Delaware cases such as Van Gorkom, ${ }^{110}$ Unocal, $^{111}$ and Caremark. ${ }^{112}$

Again, as in the United States, the takeover market (albeit a diluted version thereof) played a role in delivering the bad news about managerial inefficiency to Japanese boards. Leading business journals and even a research committee working under the auspices of MITI have recently published lists of companies that, by various measures, are attractive acquisition targets. ${ }^{113}$ As the MITI research committee's

${ }^{108} I d$. at 255.

${ }^{109}$ See Rock, supra note 1, at 1016 ("[T]he Delaware courts generate in the first instance the legal standards of conduct... largely through what can best be thought of as 'corporate law sermons.' ... Taken as a whole, the Delaware opinions can be understood as providing a set of parables....").

${ }^{110}$ Smith v. Van Gorkom, 488 A.2d 858 (Del. 1985).

111 Unocal Corp. v. Mesa Petroleum Co., 493 A.2d 946 (Del. 1985).

${ }^{112}$ In re Caremark Int'l Inc. Derivative Litig., 698 A.2d 959 (Del. Ch. 1996); see, e.g., Seiichi Okazaki, $M \mathcal{E}^{\top} A$ no koshō to torishimariyaku no keiei handan [MËA Negotiations and Directors' Business Judgment], 1562 SHōjI HōMU 18 (2000) (Part I), 1563 SHōjI HŌMU 27 (Part II), and 1566 SHōjı HōMU 22 (Part III).

${ }^{113}$ See, e.g., MBO KENKYū KaI [MBO RESEARCH GROUP], WAGA KUNI NI OKERU MBO DONYū NO IGI TO SONO FUKYū NI MUKETE NO KADAI [THE SIGNIFICANCE OF THE INTRODUCTION OF MBOS INTO OUR COUNTRY AND ISSUES RELATED TO THEIR DIFFUSION] 3, 4 (1999) [hereinafter MBO RESEARCH GROUP] (listing attractive targets 
report notes:

Among Japanese firms, many have balance sheets loaded with nonperforming assets.... There are 33 publicly traded firms [identified by name in the report] in which net cash balances exceed market capitalization. In an age in which efficiency is given higher priority than expansion, managers must bear fundamental responsibility for such inefficient utilization of assets. ${ }^{11:}$

This report represents perhaps the most blatant of several recent attempts at norm manipulation by state actors.

Unlike the situation in the United States, however, the evolution of Japanese norms on board role and structure can also be traced to the work of an identifiable norm entrepreneur. In 1997, Sony undertook significant board reform, shrinking the size of its board from thirty-eight to ten (seven executive and three outside directors) and introducing the executive officer [shikkō yakuin] structure, which has no legal foundation under the Japanese Commercial Code. The seven executive directors and twenty-seven presidents of the various Sony companies comprise the executive officers. ${ }^{115}$ Sony's reform, which was widely reported in the business and legal press, appears to have been a tipping point in board belief systems. Orix and other major firms quickly followed Sony's extra-legal innovation. Within one year of Sony's move, over 100 firms had adopted similar reforms. ${ }^{116}$ Within two years, the number of adopting firms approached $200 .{ }^{117}$

This extralegal arrangement does have a significant legal advantage for the firms adopting it. Because the Japanese Commercial Code does not recognize officers as a corporate organ, only directors (and statutory auditors) are liable to the corporation for breaches of duty. Thus, Sony-style board reform not only facilitates board monitoring and strategic decision making, it also reduces the available tar-

based on Net Cash to Market Capitalization Ratio and Takeover Recovery Cost Ratio); Masatoshi Kikuchi, TOB sareyasui kigyo 25 sha [25 Firms for Which a Tender Offer Could Easily $B e \mathrm{Made}$, EkONOMISUTO, Mar. 14, 2000, at 60,61 (listing attractive targets based on asset values and other factors).

"1* MBO RESEARCH GROUP, supra note 113 , at 3.

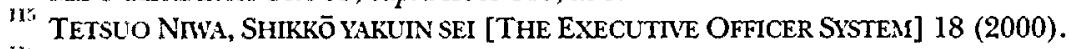

IIt DIRECTOR INNOVATION, supra note 20, at 20-21. This marked Sony's second pioneering departure from the regulatory prohibition norm. In 1995, it bypassed legal obstacles to the issuance of stock options through creative use of bonds with detachable warrants.

${ }^{17}$ Shikkō yakuin donyū kasoku [Acceleration of Adoption of Executive Officer System], Nihon KeIZAI ShInIBUN, June 25, 1999, at 3 (indicating that 179 companies adopted the system). 
gets of shareholder derivative litigation. ${ }^{118}$

\section{Lifetime Employment}

Lifetime employment remains the stickiest of all the corporate governance norms. On one hand are data portending an eventual decline in this institution. A Labor Ministry survey indicates that many major firms plan to eliminate jobs, and the rate of soon-to-be college graduates who have yet to find employment is at a record high, indicating that firms have cut intake into the lifetime employment system. ${ }^{119}$ Moreover, the market appears to be rewarding firms that depart from the norm, and punishing those that continue to abide by it. ${ }^{120}$ There have been several large layoffs recently, including 20,000 at NTT, 21,000 at Nissan, and 17,000 at Sony. Anecdotal evidence also suggests that younger workers place higher value on meritbased pay and promotions over long-term job security.

Yet adherence to the job security norm is dying hard, despite widespread acknowledgment of serious over-employment in the ranks of middle management. As one Japanese newspaper recently put it (complete with misrepresentation of history), "Most Japanese companies intend to maintain the lifetime employment system, despite growing criticism that the centuries-old practice is destroying the economy." The large layoffs to date have mostly involved firms already at the fringes of Japanese corporate norm compliance, such as Sony and Nissan, which is now controlled by Renault. A recent survey indicates

${ }^{118}$ Indeed, popular "how to" books on the officer system aimed at white-collar workers tout this legal advantage. See MANABU HAYASHIDA \& MAMORU NANAMCRA, JINZAI KATSUYō BIGU BAN [THE BIG BANG IN UTIIIZING HUMLAN RESOURCES] 138 (2000). If these board reforms were motivated solely by the fear of liability, see Mark $D$. West, Why Shareholders Sue: The Evidence from Japan 11 (Nov. 2000) (unpublished manuscript, on file with Social Science Research Network), available at http://papers.ssrn.com/sol3/papers.cfm?cfid $=4286048$ cftoken $=85393283 \&$ abstract_id $=251012$, they would appear to be an overreaction to the legal environment. It is also possible that the executive officer system merely ratifies existing practice, in which actual decisionmaking authority is vested not in the whole board, but in a small subset of the most senior board members.

${ }^{119}$ Shuichi Ito, The Changing Corporate Climate in Japan, J. JAPANESE TRADE \& INDUSTRY, Mar. 1, 2000, axailable at 2000 WL 19832771.

${ }^{120}$ There are several reports of abnormal returns on the stock of firms that announce layoffs. See Kishiko Hisada et al., Japan Sticks to Lifetime Job System, As:AHI SHIMBUN, Dec. 2, 1999, at 4, available at 1999 WL 17701748 (reporting that one corporation's stock price more than doubled after it announced layoff plans); Shishido, supra note 38, at 7. Moody's Investor Service lowered the ratings of companies that intend to maintain lifetime employment. Hisada et al., supra, at 4.

${ }^{121}$ Hisada et al., supra note 120, at 1. 
that a majority of companies plan to maintain the lifetime employment system; most are seeking to reduce employment through natural or incentivized attrition. ${ }^{122}$ Finally, a comprehensive study of survey results and qualitative data has found little support for the rhetorical claim that lifetime employment practices are coming to an end. ${ }^{123}$

\section{NORUS IN COMPARATIVE CORPORATE LAW SCHOLARSHIP}

As noted in the Introduction, norms have been largely ignored in the comparative corporate governance debates of the past decade. Perhaps this was understandable in the first phase of such scholarship, which was preoccupied with exposing the political leitmotif of a given country's financial laws and resulting corporate structures. Grappling with norms seems inevitable, however, now that scholarly attention has turned toward two interrelated questions: whether law matters to corporate ownership and finance around the world and whether corporate governance systems are converging, particularly toward an Anglo-American, shareholder-centered model. In this Part, I draw on Japan's experience with norms and corporate governance to inform analysis of these questions.

\section{A. (Non)Law Matters}

Comparative corporate law scholarship appears to have entered a new era. Politics is out; law is in. For a decade, the literature was dominated by a search for the effects of politics on corporate governance structures. Large financial intermediaries and concentrated shareholdings were viewed as attractive (or at least equally compelling) alternatives to stock markets and dispersed ownership, since political contingencies, not economic rationale, were deemed to be determinative of corporate finance, structure, and monitoring. Now a provocative new line of empirical scholarship has emerged to challenge this view. This literature, which is dominated by economists, holds that variations in law and its enforcement are key to understanding why corporate owmership and finance differ across countries. ${ }^{123} \mathrm{~A}$

Id. at 3 .

W' Se Takao Kato, The End of "Lifetime Employment" in Japan?: Evidence from National Surveys and Field Research (Jan. 31, 2001) (unpublished manuscript, on file with author).

${ }^{1: 4.4}$ For a review of this literature by its principal proponents, see Rafael La Porta et al., Investor Protection and Corporate Governance (2000) (unpublished manuscript, on file with Social Science Research Network), available at http://papers.ssrn.com/ 
series of studies shows that the origin of a given country's legal system and the quality of its law enforcement are statistically correlated with patterns of share ownership, the cost of capital, and other corporate governance variables. In contrast to the political approach, this scholarship suggests that dispersed ownership is a sign of good legal protection of minority investors. Because common law systems apparently outperform civil law regimes on investor protection, more robust capital markets and more dispersed ownership exist in countries adhering to the common law tradition. ${ }^{125}$

Few legal academics would dispute the assertion that corporate, securities, and bankruptcy law matter to corporate governance, and the statistical significance of the results in these studies must be taken seriously. Yet the empirical results are more puzzling than the authors of these studies admit and the implications for reform more attenuated than a naive reading of the literature would suggest. Here I wish to highlight several problems and limitations inherent in the new "law matters" literature by bringing norms, particularly Japan's experience with norms and corporate governance, into focus.

First, the statistical correlation between formal legal protections and corporate governance patterns revealed by these studies is in tension with the results of important natural experiments in transition economies, including Japan's. In a recent paper, the authors of the seminal "law matters" literature imply that the occupation legal reforms had a significant impact on Japanese corporate governance. ${ }^{12 n}$ As we have seen, however, enhanced investor protections in the corporate and securities laws of precisely the type recommended in the new literature had virtually no impact on Japanese corporate practices or shareholding patterns for several decades. Share ownership was widely dispersed in the immediate postwar period, but this was the direct result of the forced dissolution of the zaibatsu, a key occupation policy. In fact, as Table 4 shows, the decades following the occupation-imposed improvements in formal legal protection of minority investors in Japan are characterized by a steady concentration of share ownership in the hands of large financial and corporate investors. This is not surprising, given the complementarities between concentrated share ownership, particularly by financial institutions, and the

\footnotetext{
sol3/papers.cfm? cfid=408152\&cftoken $=41757136 \&$ abstract_id $=183908$.

${ }^{125}$ See id. at 29 (“[S] trong investor protection is associated with effective corporate governance, as reflected in valuable and broad financial markets, dispersed ownership of shares, and efficient allocation of capital across firms.").

${ }^{126} \mathrm{Id}$. at 25.
} 
operation of nonlegal rules on takeovers, main bank operations, board structure, and employment. Unsurprising, perhaps, but in direct tension with the thrust of the "law matters" literature. Significant changes in share ownership patterns became evident only recently, coinciding with the breakdown of normative corporate governance and the formation of coalitions to lobby for reform of corporate law. ${ }^{127}$

\section{Table 4: Share Ownership of Japanese Public Companies (Selected Shareholders) ${ }^{128}$}

\begin{tabular}{|c|c|c|c|c|}
\hline Year & $\begin{array}{c}\text { Financial In- } \\
\text { stitutions }\end{array}$ & Corporations & Individuals & $\begin{array}{c}\text { Foreigners } \\
\text { (Corp. \& Indiv.) }\end{array}$ \\
\hline 1949 & $9.9 \%$ & $5.6 \%$ & $69.1 \%$ & - \\
\hline 1950 & $12.6 \%$ & $11.0 \%$ & $61.3 \%$ & - \\
\hline 1955 & $23.6 \%$ & $13.2 \%$ & $53.2 \%$ & $1.7 \%$ \\
\hline 1960 & $30.6 \%$ & $17.8 \%$ & $46.3 \%$ & $1.3 \%$ \\
\hline 1965 & $29.0 \%$ & $18.4 \%$ & $44.8 \%$ & $1.8 \%$ \\
\hline 1970 & $32.3 \%$ & $23.1 \%$ & $39.9 \%$ & $3.2 \%$ \\
\hline 1975 & $36.0 \%$ & $26.3 \%$ & $33.5 \%$ & $2.6 \%$ \\
\hline 1980 & $38.8 \%$ & $26.0 \%$ & $29.2 \%$ & $4.0 \%$ \\
\hline 1985 & $42.2 \%$ & $24.1 \%$ & $25.5 \%$ & $5.7 \%$ \\
\hline 1990 & $45.2 \%$ & $25.2 \%$ & $23.1 \%$ & $4.2 \%$ \\
\hline 1995 & $41.4 \%$ & $23.6 \%$ & $23.6 \%$ & $9.4 \%$ \\
\hline 1996 & $41.3 \%$ & $23.8 \%$ & $23.6 \%$ & $9.8 \%$ \\
\hline 1997 & $40.2 \%$ & $24.1 \%$ & $24.6 \%$ & $9.8 \%$ \\
\hline 1998 & $39.3 \%$ & $24.1 \%$ & $25.4 \%$ & $10.0 \%$ \\
\hline 1999 & $36.1 \%$ & $23.7 \%$ & $26.4 \%$ & $12.4 \%$ \\
\hline
\end{tabular}

Second, norm analysis exposes theoretical weaknesses in the speci-

${ }^{1.7}$ On the relationship between coalitions and corporate law reform, see John C. Coffee, Jr., Convergence and Its Critics: What are the Preconditions to the Separation of Ownership and Control? (Sept. 12, 2000) (unpublished manuscript, on file with Social Science Research Network), available at http://papers.ssrn.com/sol3/ papers.cfm? cfid=428604\&cftoken=85393283\&:abstract_id=241782. One good example is the re-establishment of an independent securities regulator in Japan. As noted above, the occupation reformers created an SEC-style agency, but it was viewed as irrelevant and disbanded as soon as they left. It took forty years for it to be reestablished, after a series of scandals in the 1980 s and 1990 s created widespread dissatisfaction with the largely informal and nontransparent regulation of the Ministry of Finance.

${ }^{12 x}$ Zenkoku shōken torihiki kyōgikai [Securities Exchange Council of Japan], $\mathrm{He}$ isei 11 nendo kabushiki bunpu jōkyö chösa kekka ni tsuite [On the Results of the 1999 Survey of Shar' Distribution], at 10, Graph I-3, June 26, 2000. 
fication of the model underlying the "law matters" literature. In the model, ownership concentration, external finance, or some other corporate governance variable is regressed on a set of variables designed to control for the quality of legal protection afforded investors, including both shareholders and creditors. Some variables measure substantive shareholder protections, with a focus on voting rights in the election of directors and other important corporate matters. Others quantify substantive creditor rights in liquidation and reorganization procedures when borrowers default. The model also includes summary variables such as survey-based estimates of the "rule of law" and the "efficiency of the judicial system," which are designed to control for the quality of law enforcement. While the model has produced statistically significant correlations between the legal variables and the corporate governance variables, it is not clear what is being measured. The extent to which legal rules are enforced is not necessarily a function of the "quality" of a legal system or the "efficiency" of the judiciary, even assuming those attributes can be quantified. We have seen that on the level of positive law, several areas of Japanese corporate and securities regulation are virtually identical to the American provisions on which they were based, yet levels of enforcement of these provisions differ dramatically between the two countries for reasons that are unlikely to be captured in the standard indices. Moreover, while it is firmly established that social norms can substitute for law on the level of substance, remedies, and enforcement, the model does not-and probably cannot-control for these substitution effects. In short, the "law matters" model is operationalized in a manner that is inconsistent with legal theory and historical experience.

So then, what to make of the results? Perhaps, as the authors themselves suggest, the legal variables are simply a proxy for climates that are hostile or friendly toward institutional development. ${ }^{12 !}$ Indeed, it would be interesting to investigate further the correlation between legal regimes and normative environments. Some preliminary work along these lines has been done, ${ }^{130}$ but the field is wide open for inquiry.

Third, the empiricists may have reversed the actual chain of causa-

${ }^{129}$ Rafael La Porta et al., Legal Determinants of External Finance, 52 J. FIN. 1131, 1149 (1997).

${ }^{130}$ See, e.g., Rafael La Porta et al., Trust in Large Organizations, 87 AM. ECON. REV., PAPERS AND Procs. Of THE HUNDREd AND NinTH ANN. MEeting OF THE AM. ECON. ASs'N, May 1997, at 333 (finding that countries with more dominant hierarchical religions have, among other things, less efficient judiciaries and more corruption). 
tion between law and corporate governance. Law and its enforcement may not determine the structure of corporate groups; rather, important corporate and financial groups in a given society may drive the development of legal institutions and enforcement practices by affecting the demand for law, at least in part through norm creation and destruction. ${ }^{131}$ This, at least, is what I have argued above with respect to Japan. Another salient example of this phenomenon is the prevalence of concentrated share ownership throughout East Asia. In many of these countries, family control and succession is a socially valued practice that has persisted through innumerable changes in legal regime. It takes a legal centrist in the extreme to believe that the South Korean chaebol, for example, could be disbanded (or never would have emerged) if the corporate code simply contained provisions on cumulative voting, preemptive rights, and the other minority protections emphasized in the empirical literature. Where powerful enterprise groups already exist, they constitute major antagonists against the adoption and enforcement of laws that alter the balance of power between controlling and minority shareholders. At the very least, the Japanese example indicates that significant time lags-half a century in Japan's case-may be present between legal reforms and corporate governance effects.

This causation analysis provides broader perspective on Professor John Coffee's argument that legal developments tend to lag behind economic change. ${ }^{132}$ Sometimes, as Coffee argues, legal developments must await the formation of motivated coalitions to lobby for new protections. Probably more often, however, motivated coalitions block or dilute legal developments adverse to their narrow interests. At other times, particularly when law is shaped by foreign advisors or occupying

1) The authors of the empirical studies seek to rebut this criticism by claiming that legal origin is exogenous and pointing out that the legal origin variable remains significant even when holding other variables constant. It is unlikely that a legal system is completely exogenous, however, even where a colonizing or accupying force has imposed it. More importantly, the validity of the classification scheme used to create the legal origin variable is highly suspect. For example, these studies list Japan as belonging to the German civil law family. This is partially, but only partially, true of Japan's five major codes, which were adopted around the turn of the last century. But many subsequent Commercial Code revisions and important economic regulatory statutes are of U.S. origin. German law has had only a minor influence on postwar Japanese legal developments. Thus, the classification for Japan is only partially accurate and no theory is offered to explain why legal origin, as opposed to subsequent legal developments, would be determinative of corporate governance patterns. It would not be surprising if the classifications of legal origin for other countries in the study were subject to similar defects.

'Coffee, supra note 127 , at 9 . 
forces, legal developments outpace the absorptive capacities of society. Fourth, the policy implications of these studies are open to multiple interpretations. As other commentators have pointed out, it may be overly optimistic to interpret these studies as suggesting that countries simply need to improve their corporate law (that is, to enact the list of investor protections that correlate empirically with desirable results) in order to improve corporate governance. A less sanguine view is that legal rules are highly complementary within a given legal system, so that legal improvements require reforms of entire legal systems. ${ }^{133}$ Norm analysis, and the Japanese experience with norms in particular, suggests an even more pessimistic interpretation: the complementarities at work in corporate structure and finance go well beyond the components of the formal legal system, encompassing social norms and their enforcement. The good news here is that norms are subject to change; the bad news is that the process may be even more difficult and unpredictable than reforming entire legal systems. In the Japanese case, we have seen that corporate norms may be the product of interest group dynamics and that their informal character can subject the process of reform to the happenstance of exogenous shocks and the appearance of norm reformers. If, as seems most plausible, differences in corporate finance and governance are due to institutional (and not exclusively legal) differences, including the constraints people carry in their own heads, a vast amount of social engineering remains even after legislators and courts begin to function. Japan's ongoing struggle to reform its corporate governance and financial system indicates the importance and difficulty of changing mindsets, not just legal rules.

Although nothing in the postwar Japanese experience refutes the empirical finding that law matters to corporate governance and finance, the Japanese case seriously challenges researchers and policymakers to refine their understanding of this relationship. For example, Japan shows that substitutes to legal institutions can operate effectively and at low cost, at least in certain environments. Thus, questions such as how nonlegally enforceable constraints emerge and persist, whether they are efficient in comparison to available alternatives, and the policy implications of norm-based governance deserve

${ }^{133}$ Erik Berglöf \& Ernst-Ludwig von Thadden, The Changing Corporate Governance Paradigm: Implications for Transition and Developing Countries 5 (June 1999) (unpublished manuscript, on file with Social Science Research Network), availably at http://papers.ssrn.com/sol3/papers.cfm?cfid $=428604 \&$ cftoken $=85393283$

\&abstract_id=183708. 
increased scholarly attention. Norm analysis suggests the need to reconceptualize the linkage between the "rule of law" and economic structures to accommodate more than the simple focus on formal rules enforced by courts that dominates the early phases of the new comparative corporate governance literature.

\section{B. Normative Convergence}

One of the few exceptions to the absence of norms from the comparative corporate governance literature is a recent article by Professors Henry Hansmann and Reinier Kraakman entitled The End of History for Corporate Law. ${ }^{134}$ Despite the title, Hansmann and Kraakman seem principally concerned not with law, but with ideology. Indeed, they assert that corporate law had largely converged worldwide by the end of the nineteenth century. ${ }^{135}$ Yet basic legal convergence clearly did not dictate twentieth-century global consensus on the appropriate structure, financing, or conduct of corporate affairs. Thus, the central claims of the paper relate to corporate norms - which for Hansmann and Kraakman means ideologies about how firms ought to be runand their impact on corporate practices. They argue:

$[A] t$ the beginning of the twenty-first century we are witnessing rapid convergence on the standard shareholder-oriented model as a normative view of corporate structure and governance. We should also expect this normative convergence to produce substantial convergence in the practices of corporate governance and in corporate law.

These are bold claims, the accuracy of which has crucial implications for corporate actors and scholars everywhere. It is fair to ask whether the two claims in this passage accurately describe developments in Japan, the world's second largest economy and longstanding model of bank-centered corporate governance. Is Japan rapidly embracing a shareholder-centered ideology? Part III of this Article suggests that the answer is both yes and no. Certainly there are signs of important norm shifts under way in Japanese business and government: increased acceptance of the takeover as a legitimate tool of corporate strategy and monitoring (and a concomitant reduction of legal and structural impediments to M\&A), a heightened awareness of shareholders' economic expectations, a change in managerial mindset

${ }^{1.35}$ Henry Hansmann \& Reinier Kraakman, The End of History for Corporate Law, 89 GEO. L.J. 439 (2001).

Id. at 439 .

${ }^{1 \text { "n }}$ Id. at 443 . 
about its proper role in running the firm, diminished social expectations of forbearance on the part of banks and their regulators, and rising ambivalence about the benefits of seniority-based employment practices. These shifts are palpable and important. Taken together with the emerging evidence of parallel norm shifts under way in Europe, they portend a much narrower ideological spectrum on how and for whose benefit firms should be managed.

At the same time, the rapidity and extent of Japanese normative convergence toward the Anglo-American model should not be overstated. While signs of norm shifts are very recent, evidence of the inefficiency of the old norm structure surfaced nearly a decade ago. And signs of norm stickiness are abundant. To take just one example, the U.K. telecommunications firm Cable \& Wireless, which recently made a contested bid for a Japanese firm, interviewed seventeen Japanese law firms, including several with which it had ongoing professional relationships, before it found a single one willing to represent it in connection with its bid. ${ }^{137}$ Similar reputational concerns serve as a continuing constraint on domestic financing for hostile bidders. ${ }^{138}$

Complete analysis of Hansmann and Kraakman's first claim would require a deeper inquiry into the process of norm change than is possible here. But three cautionary notes suggest that it may be premature to consign alternate corporate governance models (all of which, ultimately, rest on a thick bed of nonlegal practices and customs) to the dustbin of history. First, the informality of norms can frustrate their reform because there is no established procedure for norm amendment. ${ }^{139}$ Whether existing norms in a given system are malleable or rigid turns on the magnitude of private benefits they generate and the willingness of state actors to participate in the norm manipulation process. Second, like law, norms are deeply intertwined with special interests. A priori, there is no basis for concluding that norm reform is more impervious to the effects of capture than its legal counterpart. Thus, there is no reason to believe that corporate governance norms around the world are poised to yield uniformly to a more efficient set of norms. Third, it seems unlikely that countries can embrace the shareholder supremacy norm for corporate activity

${ }^{137}$ Interview Transcript N (Tokyo, June 29, 2000).

${ }^{138}$ Interview Transcript A (Tokyo, June 19, 2000); Interview Transcript J (Tokyo, June 27, 2000).

${ }^{139}$ Robert D. Cooter, Decentralized Law for a Complex Economy: The Structural Approach to Adjudicating the New Law Merchant, 144 U. PA. L. REV. 1643, 1655 (1996) (discussing H.L.A. HART, THE CONCEPT OF LAW (1961)). 
without wholesale revision of deeply entrenched views and practices in other areas of society.

Turn now to the linkage between normative convergence and convergence of corporate law and practices. Japan provides modest support for the claim that normative convergence is leading to changes in corporate governance practices. At the margins, for example, norm shifts are influencing the selection of governance technologies. One example is increased interest in the management buyout as an acquisition technique. Perceived consistency between the MBO and past Japanese business practices is often stressed, even by the government, as a reason why this technique may be appropriate for Japan. ${ }^{14}$ The $\mathrm{MBO}$ is attractive because it has the potential to meld two conflicting Japanese norms: the emergent concept of shareholder primacy and the more longstanding focus on employee welfare. To date, however, while MBO funding is available, few deals have emerged because the technique has not caught on with Japanese managers. ${ }^{\text {i1 }}$

Yet normative convergence does not necessarily imply that formal convergence will follow inexorably. Sometimes normative convergence outpaces legal reform and must coexist at least temporarily with conflicting institutions. Japanese board reform is a good example of this phenomenon. While Sony-style board reform was driven in part by normative convergence, it has not yet led to changes in corporate law. There is no legal recognition of executive officers as a corporate organ, and thus executive officers are not legally accountable to shareholders. $^{142}$ Nor for that matter has normative convergence in this area led to complete functional convergence. Japanese directors and officers still play different roles than their U.S. counterparts.

What seems more probable than a tight correlation between normative and formal convergence is a regime of constrained pluralism among national corporate governance practices. That is, for all but the most international of firms, practices will continue to diverge, based as they are on a welter of different informal understandings and

14" MBO RESEARCH GROUP, supra note 113, at 7 (1999) (emphasizing that the MBO may be comparatively easy to introduce into Japan because, in contrast to other forms of M\&A, (1) it is similar to an existing Japanese business practice known as normwake and (2) it generally does not entail mass layoffs).

1:1 Interview Transcript $\mathrm{K}$, supra note 96.

" 2 Proposals to amend the Commercial Code to legally recognize executive officers and subject them to derivative suits are pending, however. Shikkō yakuin ni mo loöteki sekinin [Legal Liability for Executive Officers Too], NHHON KEIZAI SHIMBUN, Dec. 5, 2000, at 1 . 
exogenous stimuli. But those practices will operate within a spectrum of acceptable corporate governance goals and beneficiaries made narrower by general consensus on major issues such as the need to prevent expropriation of minority investments and the responsibility of management to explain its decisions to shareholders.

At a fairly high level of generality, then, Professors Hansmann and Kraakman have provided a provocative account of one of the principal mechanisms driving corporate convergence: the ascendance of the shareholder primacy norm. In so doing, they have highlighted an understudied aspect of comparative corporate governance. Ultimately, however, their claims may be overstated, deflecting attention from what promises to be the key challenge for many transition countries, including Japan, in the decade ahead-the struggle to realign the formal and informal components of their corporate governance institutions into a complementary whole. As the experience of Japan and other transition economies over the past decade suggests, this process will be complicated by the extraordinarily unpredictable process of changing institutions by changing the way people think. For the economic and political actors in these countries, it is not the end of history, but the beginning of time.

\section{CONCLUSION}

Nonlegal rules and their relationship to formal institutions are important to our understanding of Japanese corporate governance. Inquiry into the origins of prevailing corporate norms reveals that, contrary to common assertions, none enjoy a long history of practice in Japan. Rather, these norms appear to have emerged in response to the peculiarities of the formal postwar institutional environment. Norms provided a low-cost substitute for legal governance mechanisms in the institutional turmoil of the immediate postwar period, when Japan was beset by the transplant effect that so commonly disrupts legal reform in transitional societies. The norms arising at that time had particular resiliency because they supplied private benefits to interest groups left intact after the war, including key governmental actors.

Today, the norms of postwar Japanese corporate governance are being destroyed-some dramatically, others more gradually-by a confluence of forces captured in the academic models of norm reform: increased information, exogenous shocks, the workings of norm entrepreneurs, and state-led norm manipulation.

Examination of the postwar Japanese experience with norms and 
corporate law highlights the absence of norm analysis in comparative corporate law scholarship. Bringing norms into focus contributes to the debates on convergence and corporate law enforcement that dominate the literature today and highlights several weaknesses in existing analyses of these issues. 
$* \quad * \quad * \quad * \quad * \quad *$ 